\title{
Aerosol size distribution and radiative forcing response to anthropogenically driven historical changes in biogenic secondary organic aerosol formation
}

\author{
S. D. D'Andrea ${ }^{1}$, J. C. Acosta Navarro ${ }^{2}$, S. C. Farina ${ }^{1}$, C. E. Scott ${ }^{3}$, A. Rap ${ }^{3}$, D. K. Farmer ${ }^{4}$, D. V. Spracklen ${ }^{3}$, \\ I. Riipinen ${ }^{2,5}$, and J. R. Pierce ${ }^{1,6}$ \\ ${ }^{1}$ Department of Atmospheric Science, Colorado State University, Fort Collins, CO, USA \\ ${ }^{2}$ Department of Applied Environmental Science and Bert Bolin Centre for Climate Research, Stockholm University, \\ Stockholm, Sweden \\ ${ }^{3}$ School of Earth and Environment, University of Leeds, Leeds, UK \\ ${ }^{4}$ Department of Chemistry, Colorado State University, Fort Collins, CO, USA \\ ${ }^{5}$ Center for Atmospheric Particle Studies, Carnegie Mellon University, Pittsburgh, PA, USA \\ ${ }^{6}$ Department of Physics and Atmospheric Science, Dalhousie University, Halifax, NS, Canada
}

Correspondence to: S. D. D’Andrea (sdandrea@atmos.colostate.edu)

Received: 30 September 2014 - Published in Atmos. Chem. Phys. Discuss.: 20 October 2014

Revised: 29 January 2015 - Accepted: 5 February 2015 - Published: 2 March 2015

\begin{abstract}
Emissions of biogenic volatile organic compounds (BVOCs) have changed in the past millennium due to changes in land use, temperature, and $\mathrm{CO}_{2}$ concentrations. Recent reconstructions of BVOC emissions have predicted that global isoprene emissions have decreased, while monoterpene and sesquiterpene emissions have increased; however, all three show regional variability due to competition between the various influencing factors.

In this work, we use two modeled estimates of BVOC emissions from the years 1000 to 2000 to test the effect of anthropogenic changes to BVOC emissions on secondary organic aerosol (SOA) formation, global aerosol size distributions, and radiative effects using the GEOS-Chem-TOMAS (Goddard Earth Observing System; TwO-Moment Aerosol Sectional) global aerosol microphysics model. With anthropogenic emissions (e.g., $\mathrm{SO}_{2}, \mathrm{NO}_{\mathrm{x}}$, primary aerosols) turned off and BVOC emissions changed from year 1000 to year 2000 values, decreases in the number concentration of particles of size $D_{\mathrm{p}}>80 \mathrm{~nm}(\mathrm{~N} 80)$ of $>25 \%$ in year 2000 relative to year 1000 were predicted in regions with extensive landuse changes since year 1000 which led to regional increases in the combined aerosol radiative effect (direct and indirect) of $>0.5 \mathrm{~W} \mathrm{~m}^{-2}$ in these regions. We test the sensitivity of our results to BVOC emissions inventory, SOA yields, and
\end{abstract}

the presence of anthropogenic emissions; however, the qualitative response of the model to historic BVOC changes remains the same in all cases. Accounting for these uncertainties, we estimate millennial changes in BVOC emissions cause a global mean direct effect of between +0.022 and $+0.163 \mathrm{~W} \mathrm{~m}^{-2}$ and the global mean cloud-albedo aerosol indirect effect of between -0.008 and $-0.056 \mathrm{~W} \mathrm{~m}^{-2}$. This change in aerosols, and the associated radiative forcing, could be a largely overlooked and important anthropogenic aerosol effect on regional climates.

\section{Introduction}

Biogenic volatile organic compounds (BVOCs) play an important role in tropospheric chemistry and pollution by reacting with the hydroxyl radical $(\mathrm{OH})$, nitrate radical $\left(\mathrm{NO}_{3}\right)$, and ozone $\left(\mathrm{O}_{3}\right)$ (Chung and Seinfeld, 2002). BVOCs are also important precursors for $\mathrm{O}_{3}$ (Chameides et al., 1998) and secondary organic aerosol (SOA) formation (Kanakidou et al., 2005). Recent studies on historical emissions of BVOCs have shown that BVOC emissions have been affected by anthropogenic influences over the past millennium (Kaplan et al., 2011; Tanaka et al., 2012; Pacifico et al., 2012; Unger, 
2013; Acosta Navarro et al., 2014). Changes in land use, temperature, and carbon dioxide $\left(\mathrm{CO}_{2}\right)$ concentrations have all had significant impacts on the emissions of BVOCs.

Acosta Navarro et al. (2014) predicted that globally averaged isoprene emissions have decreased over the past millennium mainly due to land-use changes, which involved the conversion of high-isoprene-emitting natural shrubs and broadleaf trees to low-emitting crop and grazing land. They also predicted that globally averaged monoterpene and sesquiterpene emissions have increased over the past millennium due mainly to global increases in temperature (the monoterpene- and sesquiterpene-emitting vegetation has not decreased from land-use changes to the same degree as the isoprene-emitting vegetation). However, all three BVOC classes show both increases and decreases in various regions due to competing factors such as land-use change, increases in $\mathrm{CO}_{2}$ concentrations, and temperature change. The most dominant cause of BVOC emission changes has been from anthropogenic factors (e.g., change in land cover and $\mathrm{CO}_{2}$ effects), where land-use change has had the most dramatic impact by decreasing the isoprene emissions. These changes in BVOC emissions can have important implications on the formation rate of low-volatility SOA, which is essential for particle growth to sizes large enough to affect climate (Riipinen et al., 2011, 2012; Paasonen et al., 2013; Liao et al., 2014).

The Earth's radiation balance is directly affected by aerosol particles by absorption and scattering of solar radiation (Rosenfeld et al., 2008; Clement et al., 2009) as well as indirectly affected by aerosols by alteration of cloud properties and lifetimes (Charlson et al., 1992). The uncertainty associated with aerosol radiative forcing, particularly the aerosol indirect effect, is a large source of uncertainty in global climate models (Forster et al., 2007). Recent studies suggest that this uncertainty is largely due to incomplete knowledge on different natural contributions to atmospheric aerosol loadings (Carslaw et al., 2013). The influence of aerosols on cloud droplet number concentration (CDNC) is driven by the number concentration of cloud condensation nuclei $(\mathrm{CCN})$, the particles on which cloud droplets form. The number concentration of $\mathrm{CCN}$ is highly dependent on the aerosol size distribution (Dusek et al., 2006; McFiggans et al., 2006; Petters and Kreidenweis, 2007; Pierce and Adams, 2007); therefore, the size-dependent number of all sizes of particles must be accurately represented to simulate $\mathrm{CCN}$ number concentrations correctly.

The two sources of aerosol number concentrations in the atmosphere are primary emissions (Putaud et al., 2004; Stanier et al., 2004) and the formation of new particles (diameter $\sim 1 \mathrm{~nm}$ ) via nucleation (Kulmala et al., 2004). In order for freshly nucleated particles or emitted nanoparticles with diameters less than $\mathrm{CCN}$ sizes $(30-100 \mathrm{~nm})$ to influence atmospheric CCN number concentrations, they must undergo condensational growth (Pierce and Adams, 2007; Vehkamäki and Riipinen, 2012). However, the survival probability of nanoparticles depends on the competition between condensational growth and coagulational scavenging with pre-existing aerosol (Kerminen and Kulmala, 2002; Pierce and Adams, 2007; Kuang et al., 2009; Westervelt et al., 2013).

The growth of particles to $\mathrm{CCN}$ sizes due to condensation of sulfuric acid is well known (Sipilä et al., 2010); however, the condensation of low-volatility organic aerosols (OA) have also recently been shown to play a substantial role in particle growth (Kerminen et al., 2012; Riipinen et al., 2011, 2012; Carslaw et al., 2010; Makkonen et al., 2012). Measurements of the submicron particle composition throughout the continental boundary layer show that $20-90 \%$ of the submicron particulate mass is OA (Jimenez et al., 2009). OA enters the atmosphere through biogenic emissions, and by anthropogenic emission sources such as vehicles and residential heating (Hallquist et al., 2009). Volatile organic compounds (VOCs), biogenic volatile organic compounds (BVOCs), and intermediate volatility organic compounds have been shown to be precursors for SOA (Donahue et al., 2011; Hallquist et al., 2009). SOA formation occurs when gas-phase, particlephase, and cloud-phase chemical processes involving VOCs form products with low enough volatility to remain in the condensed phase (Hallquist et al., 2009; Lim et al., 2010). Additionally, in regions where there is mixing of anthropogenic and biogenic species, anthropogenic species may enhance SOA formation from BVOCs (Carlton et al., 2010; Spracklen et al., 2011; de Gouw et al., 2005). Regardless of the formation mechanism, adding SOA mass to pre-existing aerosol causes a net condensational flux to the aerosol phase. This increased condensational flux can enhance the growth of ultrafine aerosols to climate-relevant sizes (Pierce et al., 2011; Riipinen et al., 2011, D'Andrea et al., 2013). Therefore, BVOC emissions have a significant impact on SOA formation, $\mathrm{CCN}$ number concentrations, and ultimately climate.

In this paper, we test the influence of anthropogenic changes in BVOC emissions on SOA formation, global aerosol size distributions, and $\mathrm{CCN}$ by using these modeled estimates of the dominant BVOC classes' emissions from the years 1000 to 2000 . The year 1000 was chosen (as opposed to the years 1750 or 1800) to not only capture pre-industrial conditions, but also account for changes in isoprene emissions prior to 1750 through human-induced land-use changes. Furthermore, we quantify the net radiative forcing associated with these anthropogenic BVOC changes. Previous studies have investigated the impacts of land-use change on aerosols and radiative forcing (Heald et al., 2008; Wu et al., 2012; Ward et al., 2014); however, this study focuses uniquely on the combination of historical perspective, comprehensive consideration of different BVOC species, and detailed aerosol microphysics (thus focusing on the aerosol number concentrations and size distributions). We do not take into account the potential effects of changing anthropogenic pollution on the yields of biogenic SOA from BVOCs because of the large uncertainties in these enhancements, but we discuss the implications of these changes. 
In the following section, we summarize the global millennial changes in biogenic emissions from Acosta Navarro et al. (2014). Section 3 describes the model used in this study and the methods used for formation of SOA from the biogenic terpenoid emissions. Section 4 describes the results, highlighting the global changes in particle size distributions due to the millennial changes in BVOC emissions and the climatic implications associated with these changes.

\section{Overview of predicted BVOC emissions changes}

Acosta Navarro et al. (2014) used the Model of Emissions and Gases and Aerosols from Nature (MEGAN) (Guenther et al., 2006) and the Lund-Potsdam-Jena General Ecosystem Generator (LPJ-GUESS) (Smith et al., 2001; Sitch et al., 2003) to reconstruct BVOC emissions from the year 1000 to the year 2000. This is described in detail by Acosta Navarro et al. (2014), but will be summarized here. For this study, we refer to the decadal-averaged BVOC emissions using MEGAN from 1000-1010 and from 1980-1990 as years 1000 and 2000, respectively, for simplicity. We refer to the annual-averaged BVOC emissions using LPJ-GUESS from years 1000 and 2000 as years 1000 and 2000, respectively. Because our LPJ-GUESS emissions are from one single year at 1000 and 2000, these data may be susceptible to some regional biases due to not capturing interannual variability.

The MEGAN reconstruction includes all three BVOC classes, whereas the LPJ-GUESS reconstruction includes only isoprene and monoterpenes. MEGAN and LPJ-GUESS were run in a series of simulations testing sensitivities to variables (such as plant functional type, leaf area index, soil water content, annual $\mathrm{CO}_{2}$ concentrations, land-use cover, and anthropogenic vegetation types such as crops and pastures), and millennial terpenoid BVOC emission inventories were created (Acosta Navarro et al., 2014). The main driving factors behind the changes are not always the same (for details see Acosta Navarro et al., 2014).

The terpenoid BVOC emissions in Acosta Navarro et al. (2014) are sensitive to variations in meteorological conditions and land-use changes, but are also sensitive to the empirical standard emission factors used in the developing of the inventory. Plant emission factors of the three BVOCs were averaged over wide plant families in order to make the model computationally feasible. Therefore, the changes in isoprene, monoterpenes, and sesquiterpenes in the reconstruction are indicators of the response of the three BVOCs to external stresses and land-use change, rather than exact emission estimates. Also, changing the resolution of the emissions inventory from the original resolution to a coarser resolution may inherently have uncertainties.

Isoprene has the highest predicted emission rates of the BVOCs investigated in this study with emissions averaged over the time period 1000-1990 greater than $50 \mathrm{mg} \mathrm{m}^{-2} \mathrm{day}^{-1}$ using MEGAN and greater than
$30 \mathrm{mg} \mathrm{m}^{-2}$ day $^{-1}$ averaged over the period $1000-2000$ using LPJ-GUESS over tropical rainforests (Acosta Navarro et al., 2014). These emissions are roughly a factor of 100 lower over mid-latitude forests. Isoprene emissions are dominant in tropical and sub-tropical regions but much lower in boreal regions. Predicted absolute changes in the spatial distribution of mean isoprene emissions from 1000 to 2000 using MEGAN and LPJ-GUESS are shown in Fig. 1a and b, respectively. Globally averaged, predicted isoprene emissions over this period decrease by $21 \%$ in MEGAN and $23 \%$ in LPJ-GUESS, and these decreases are due predominantly to cropland expansion and $\mathrm{CO}_{2}$ concentration effects (Acosta Navarro et al., 2014). The changes in land-use due to natural high isoprene-emitting broadleaf trees and shrubs being converted to low-isoprene-emitting crops and grasses, such as in plantations and pastures, have directly decreased isoprene emissions regionally in both reconstructions. The tropical and sub-tropical regions with high isoprene emissions are the regions with the largest absolute changes in emissions over this time period. There is some evidence for decreases in isoprene emissions with increasing $\mathrm{CO}_{2}$ concentrations, although the related mechanisms are not well understood (Peñuelas and Staudt, 2010). The effects are included in MEGAN and LPJ-GUESS, so both of the models applied by Acosta Navarro et al. (2014) suggest that increasing $\mathrm{CO}_{2}$ concentrations in the present-day atmosphere also contribute to the decrease in isoprene emissions. However, isoprene emissions in some regions where the natural vegetation has remained unaltered or increased over the past millennium have increased by greater than $50 \%$ in both reconstructions due to the increase in surface air temperature (Acosta Navarro et al., 2014).

Along with changes in isoprene emissions over the past millennium, predicted monoterpene emissions also change, but due to different environmental and anthropogenic influences. Mean predicted emissions of monoterpenes over the period 1000-2000 are roughly an order of magnitude lower than predicted isoprene emissions, but are still greater than $5 \mathrm{mg} \mathrm{m}^{-2}$ day $^{-1}$ and $0.8 \mathrm{mg} \mathrm{m}^{-2}$ day $^{-1}$ in tropical and subtropical forests in the MEGAN and LPJ-GUESS reconstructions, respectively (Acosta Navarro et al., 2014). Predicted absolute changes in the spatial distribution of mean monoterpene emissions from 1000 to 2000 using MEGAN and LPJGUESS are shown in Fig. 1c and d, respectively. Globally averaged, predicted monoterpene emissions over this period increase by $3 \%$ in MEGAN and $0 \%$ in LPJ-GUESS. However, in many regions there is an increase in predicted monoterpene emissions of approximately $0.5 \mathrm{mg} \mathrm{m}^{-2} \mathrm{day}^{-1}$. These increases are due predominantly to the development of agriculture in regions where monoterpene-emitting vegetation was previously scarce (Acosta Navarro et al., 2014). There are significant regions of decreasing monoterpene emissions in both reconstructions (blue regions) due to strong deforestation and a replacement of natural vegetation with low monoterpene-emitting species (Acosta Navarro et al., 2014). 

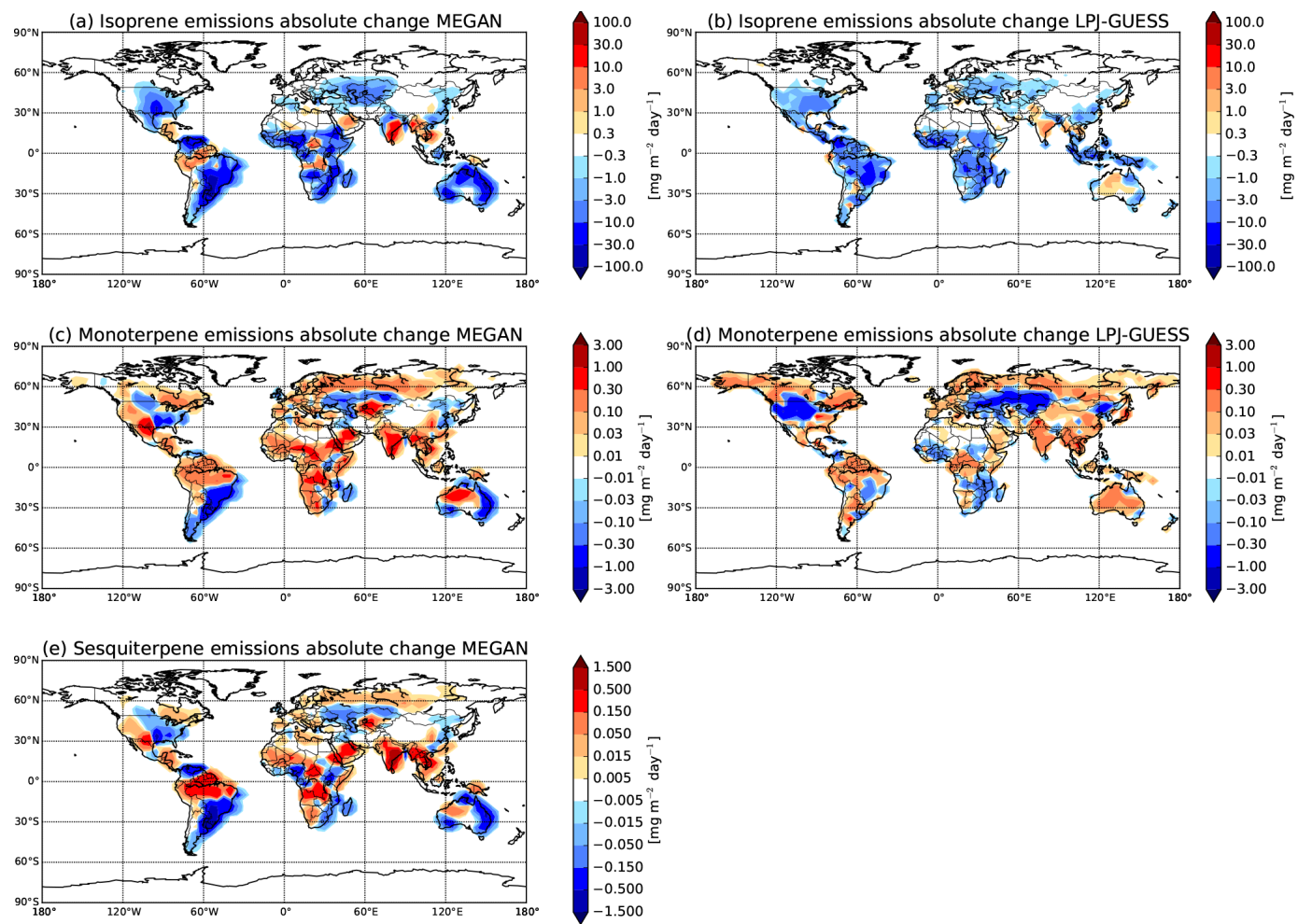

Figure 1. Absolute change in (a) isoprene, (c) monoterpene, and (e) sesquiterpene emissions between the years 1000-1010 and 1980-1990 in $\mathrm{mg} \mathrm{m}^{-2}$ day $^{-1}$ from the MEGAN terpenoid reconstruction, and absolute change in (b) isoprene, and (d) monoterpene emissions between the years 1000 and 2000 in $\mathrm{mg} \mathrm{m}^{-2}$ day $^{-1}$ from the LPJ-GUESS terpenoid reconstruction (Acosta Navarro et al., 2014). Note the change of scale between panels. An increase in emissions is represented in red, and a decrease in isoprene emissions in blue.

It is worthwhile to note that the effect of $\mathrm{CO}_{2}$ concentrations on monoterpene emissions is still under debate, and was not included in the simulations by Acosta Navarro et al. (2014) applied here. We also note that the temperature response of BVOC emissions used to predict long-term changes is derived from short-term measurements, and may not accurately reflect the adaptive behavior of plants grown under changing environmental conditions.

Similar to changes in predicted monoterpene emissions over the past millennium, sesquiterpene emissions have also been predicted to increase regionally although remaining approximately constant globally. Mean predicted emissions of sesquiterpenes over the period 1000-2000 are spatially distributed similar to that of monoterpene emissions and are an order of magnitude lower than predicted monoterpene emissions, and 2 orders of magnitude lower than predicted isoprene emissions. Figure 1e shows the absolute change in predicted sesquiterpene emissions from 1000 to 2000 using MEGAN. Following the same trend as predicted monoterpenes, the globally averaged change in predicted sesquiterpene emissions over this period increase by approximately $1 \%$. The causes of the changes in predicted sesquiterpene emissions are analogous to the changes in predicted monoterpene emissions. The changes are predominantly due to de- velopment of agriculture in regions where sesquiterpeneemitting vegetation was previously limited (Acosta Navarro et al., 2014).

\section{Methods}

We use a global chemical transport model with online aerosol microphysics to test the sensitivity of the simulated aerosol size distributions to changes in BVOC emissions from the years 1000 to 2000 , and calculate the associated radiative forcing.

\subsection{GEOS-Chem-TOMAS model description}

We use the global chemical-transport model, GEOS-Chem (Goddard Earth Observing System) (http://www.geos-chem. org), combined with the online aerosol microphysics module, TOMAS (TwO-Moment Aerosol Sectional; GEOS-ChemTOMAS) to test the sensitivity of global aerosol size distributions to changes in BVOC emissions. GEOS-Chem-TOMAS in this study uses GEOS-Chem v9.01.02 with $4^{\circ} \times 5^{\circ}$ horizontal resolution, 47 vertical layers from the surface to $0.01 \mathrm{hPa}$ with meteorological inputs from the GEOS5 reanalysis (http://gmao.gsfc.nasa.gov). TOMAS in this work 
simulates the aerosol size distribution using 15 size sections ranging from $3 \mathrm{~nm}$ to $10 \mu \mathrm{m}$ (Lee and Adams, 2011). Nucleation rates in all simulations were predicted by ternary homogeneous nucleation of sulfuric acid, ammonia, and water based on the parameterization of Napari et al. (2002) scaled globally by a constant factor of $10^{-5}$ which has been shown to predict nucleation rates closer to measurements than other commonly used nucleation schemes (Jung et al., 2010; Westervelt et al., 2013). All emissions except terpenoid biogenic emissions (monoterpenes, isoprene, and sesquiterpenes) in GEOS-Chem are described in van Donkelaar et al. (2008). The three dominant BVOC classes (monoterpenes, isoprene, and sesquiterpenes) are included in GEOSChem using modeled reconstructions as provided by Acosta Navarro et al. (2014). The emissions from Acosta Navarro et al. (2014) override biogenic emissions previously input from a different version of MEGAN (Guenther et al., 2006) in the standard version of GEOS-Chem for SOA production only and do not influence the gas-phase chemistry in GEOSChem-TOMAS. We do not consider this feedback; however, we will discuss the implications in Sect. 4.4.

Traditionally, SOA in GEOS-Chem-TOMAS is formed only from terrestrial biogenic sources, with the biogenic source being a fixed yield of $10 \%$ of the monoterpene emissions. However, isoprene and sesquiterpenes also serve as SOA precursors (Hoffmann et al., 1997; Griffin et al., 1999; Kroll et al., 2006). In this study, we form SOA from isoprene, monoterpenes, and sesquiterpenes with fixed yields of 3,10 , and $20 \%$, respectively, based on estimations summarized in Pye et al. (2010). Dynamic SOA yields through partitioning theory are computationally expensive to couple with aerosol microphysics schemes, and they tend to underpredict ultrafine particle growth when lab-based volatility distributions are used (Pierce et al., 2011), and thus are not used here. However, we test the sensitivity to these yields. The yields used in this study are on the low end of mean yield estimates; however, we test the sensitivity of SOA formation and $\mathrm{CCN}$ number concentrations to upper bounds on these yields (10, 20, and 40\%, respectively) (Pye et al., 2010) (see Table 1 for total biogenic SOA formation rates for each simulation). Biogenic SOA formation, particularly from isoprene, has been shown in chamber studies and ambient measurements to have dependencies on $\mathrm{NO}_{\mathrm{x}}$ concentrations $\left(\mathrm{NO}_{\mathrm{x}}=\mathrm{NO}+\mathrm{NO}_{2}\right)$ (Kroll et al., 2006; Kroll and Seinfeld, 2008; Carlton et al., 2009; Xu et al., 2014). SOA yield from isoprene oxidation can reach in excess of $4 \%$ under low- $\mathrm{NO}_{\mathrm{x}}$ conditions (Kroll et al., 2006) at atmospherically relevant organic mass concentrations (Carlton et al., 2009). Kroll et al. (2006) also found in chamber studies that SOA yields from isoprene oxidation can reach in excess of $5 \%$ at $\mathrm{NO}_{\mathrm{x}}$ concentrations of approximately $100 \mathrm{ppb}$. Over the past millenium, there have been increases in agriculture, anthropogenic biomass burning, and industrial activity leading to enhanced $\mathrm{NO}_{\mathrm{x}}$ emissions (Benkovitz et al., 1996), which potentially impact SOA yields. More sophisticated SOA for- mation mechanisms that account for $\mathrm{NO}_{\mathrm{x}}$-dependent yields might improve model representation; however, maximum $\mathrm{NO}_{\mathrm{x}}$ concentrations in GEOS-Chem-TOMAS are approximately an order of magnitude lower than the concentrations used in the chamber study by Kroll et al. (2006), Lamsal et al. (2008) and therefore fall well below $\mathrm{NO}_{\mathrm{x}}$ concentrations high enough to significantly alter SOA formation rates. We note that while high absolute concentrations of any species may call into question the atmospheric relevance of chamber experiments, the $\mathrm{NO}: \mathrm{HO}_{2}$ ratio within a chamber is an equally critical parameter for describing the chemical regime of SOA formation. Therefore, for this study, biogenic SOA in GEOS-Chem-TOMAS is formed via fixed yields of isoprene, monoterpenes, and sesquiterpenes, and has no dependency on $\mathrm{NO}_{\mathrm{x}}$ concentrations. The change in emissions of isoprene, monoterpenes, and sesquiterpenes from the MEGAN and LPJ-GUESS reconstructions solely affects SOA formation, and does not influence the oxidation fields in GEOS-ChemTOMAS. Therefore, there may be missing feedback mechanisms on key atmospheric oxidants.

In this study, particles are assumed to undergo kinetic, gasphase-diffusion-limited growth with condensation of SOA proportional to the Fuchs-corrected aerosol surface area. This assumption was found to best reproduce aerosol size distribution in two recent studies (Riipinen et al., 2011; D'Andrea et al., 2013). This kinetic condensation of SOA assumes that the SOA is non-volatile (or similar to low-volatility SOA with average saturation vapor pressure, $C^{*}$, of less than approximately $10^{-3} \mathrm{\mu g} \mathrm{m}^{-3}$ ) (Pierce et al., 2011, Ehn et al., 2014). Also, as described in D'Andrea et al. (2013), an additional $100 \mathrm{Tg} \mathrm{yr}^{-1}$ of SOA correlated with anthropogenic carbon monoxide emissions is required to match present-day measurements. D'Andrea et al. (2013) evaluates GEOS-ChemTOMAS particle number concentrations against measurements and shows that including the extra SOA yields improved number predictions for a wide range of particle sizes. The sensitivity of this additional source of SOA is also investigated in this study.

We test the sensitivity of predicted size distributions to anthropogenically driven changes in BVOC emissions in GEOS-Chem-TOMAS using 12 simulations. Table 1 shows the assumptions in these 12 simulations. All simulations were run using 2005 meteorology with 3 months of spin-up from a pre-spun-up restart file.

AE2 (Anthropogenic Emissions 2000) simulations use anthropogenic emissions for the year 2005, and AEO (Anthropogenic Emissions Off) simulations (used to simulate an atmosphere more similar to pre-industrial) have anthropogenic emissions off. BE1 (Biogenic Emissions 1000) simulations use year 1000 biogenic emissions, and BE2 (Biogenic Emissions 2000) simulations use year 2000 biogenic emissions for SOA production only. Changing the biogenic emissions allows us to investigate the influence of changes to fixed-yield SOA formation only and not to the changes in atmospheric oxidants (and the subsequent changes to aerosols) associated 
Table 1. Summary of the GEOS-Chem-TOMAS simulations performed in this study. Biogenic emissions for year 1000 and 2000 using MEGAN are decadal-averaged emissions for 1000-1010 and 1980-1990, respectively, whereas LPJ-GUESS biogenic emissions are annualaveraged for the years 1000 and 2000. Standard SOA yields are 3, 10, and $20 \%$ for isoprene, monoterpenes, and sesquiterpenes, respectively, and upper-bound SOA yields are 10, 20, and $40 \%$ for isoprene, monoterpenes, and sesquiterpenes, respectively. In the simulation naming scheme, "BE" refers to biogenic emissions, "1" refers to year 1000, "2" refers to year 2000, "O" refers to off, "meg" refers to MEGAN BVOC emissions, "LPJ" refers to LPJ-GUESS BVOC emissions, "up" refers to upper-bound SOA yields, and "XSOA" refers to the inclusion of the additional $100 \mathrm{Tg}$ (SOA) $\mathrm{yr}^{-1}$.

\begin{tabular}{|c|c|c|c|c|c|c|c|c|}
\hline $\begin{array}{l}\text { Simulation } \\
\text { name }\end{array}$ & $\begin{array}{r}\text { Biogenic } \\
\text { emissions }\end{array}$ & $\begin{array}{l}\text { Anthropogenic } \\
\text { emissions }\end{array}$ & $\begin{array}{l}\text { MEGAN } \\
\text { Acosta } \\
\text { Navarro } \\
\text { et al. } \\
(2014)\end{array}$ & $\begin{array}{l}\text { LPJ- } \\
\text { GUESS } \\
\text { Acosta } \\
\text { Navarro } \\
\text { et al. } \\
(2014)\end{array}$ & $\begin{array}{l}\text { Standard } \\
\text { SOA yield }\end{array}$ & $\begin{array}{l}\text { Upper } \\
\text { bound } \\
\text { SOA yield } \\
\text { D'Andrea } \\
\text { et al. } \\
(2013)\end{array}$ & $\begin{array}{l}\text { Additional } \\
100 \mathrm{Tg}^{-} \\
(\mathrm{SOA}) \mathrm{yr}^{-1} \\
\text { formation } \\
\text { rates }\end{array}$ & $\begin{array}{r}\text { Total } \\
\text { biogenic } \\
\text { SOA } \\
\left(\mathrm{Tg} \mathrm{yr}^{-1}\right)\end{array}$ \\
\hline BE1.AE2.meg & 1000 & YES & YES & NO & YES & NO & $\mathrm{NO}$ & 35.96 \\
\hline BE1.AEO.meg & 1000 & NO & YES & NO & YES & NO & $\mathrm{NO}$ & 35.96 \\
\hline BE2.AE2.meg & 2000 & YES & YES & $\mathrm{NO}$ & YES & NO & NO & 41.44 \\
\hline BE2.AEO.meg & 2000 & NO & YES & NO & YES & NO & NO & 41.44 \\
\hline BE1.AEO.LPJ & 1000 & $\mathrm{NO}$ & NO & YES & YES & NO & NO & 13.63 \\
\hline BE2.AEO.LPJ & 2000 & $\mathrm{NO}$ & $\mathrm{NO}$ & YES & YES & NO & $\mathrm{NO}$ & 16.81 \\
\hline BE1.AE2.up & 1000 & YES & YES & $\mathrm{NO}$ & $\mathrm{NO}$ & YES & NO & 100.30 \\
\hline BE1.AEO.up & 1000 & NO & YES & NO & NO & YES & NO & 100.30 \\
\hline BE2.AE2.up & 2000 & YES & YES & NO & NO & YES & $\mathrm{NO}$ & 118.92 \\
\hline BE2.AEO.up & 2000 & NO & YES & NO & NO & YES & NO & 118.92 \\
\hline BE1.XSOA & 1000 & YES & YES & NO & YES & NO & YES & 135.96 \\
\hline BE2.XSOA & 2000 & YES & YES & NO & YES & NO & YES & 141.44 \\
\hline
\end{tabular}

with these changes in BVOC emissions. For gas-phase chemistry, emissions of BVOCs are from online MEGAN for 2005 (Wainwright et al., 2012). Using the AE2 and AEO simulations, we can see if the sensitivity of aerosols and radiative forcing to changes in BVOC emissions is strongly sensitive to the presence of anthropogenic aerosols. First, we assume present-day anthropogenic emissions and have simultaneous monthly mean BVOC emissions from MEGAN for the year 1000 (BE1.AE2.meg) and another simulation for the year 2000 also using MEGAN (BE2.AE2.meg) (the justification for these time periods is explained in Sect. 2.3). This method isolates the change in BVOCs and the effect on aerosol size distributions under fixed anthropogenic emissions. We also test the sensitivity to changes in BVOC emissions over the same periods with no anthropogenic emissions to simulate a pre-industrial anthropogenic environment using MEGAN (BE1.AEO.meg and BE2.AEO.meg) and LPJGUESS (BE1.AEO.LPJ and BE2.AEO.LPJ). Using these simulations, we also test the sensitivity of predicted size distributions to changes in anthropogenic emissions under present-day BVOC emissions from MEGAN by comparing simulations (BE2.AEO.meg and BE2.AE2.meg). Thus, we estimate the effects of changing biogenic emissions in sets of simulations where the anthropogenic emissions are either on or off. While neither of these comparisons is realistic (anthropogenic emissions changed as the biogenic emissions were changing), it allows us to bound the impact of anthropogenic emissions on the partial derivative with respect to changing biogenic emissions.

We also test the model sensitivity to changes in SOA yields (as described previously) over the same periods by repeating the four simulations using MEGAN (BE1.AE2.meg, BE1.AEO.meg, BE2.AE2.meg, and BE2.AEO.meg) with upper bounds on the SOA yields $(10,20$, and $40 \%$ of isoprene, monoterpenes, and sesquiterpenes, respectively) (BE1.AE2.up, BE1.AEO.up, BE2.AE2.up, BE2.AEO.up). Finally, we investigate the sensitivity to the inclusion of an additional $100 \mathrm{Tg} \mathrm{yr}^{-1}$ of anthropogenically enhanced SOA (as described previously) in the simulations with presentday anthropogenic emissions using MEGAN biogenic emissions for year 1000 and year 2000 conditions (BE1.XSOA, BE2.XSOA). We note that the predicted size distributions and uncertainty ranges in this paper are sensitive to the nucleation scheme, anthropogenic emissions fluxes, and emissions size (e.g., Pierce and Adams, 2009), but here we explore the modeled partial derivatives to changes in BVOC emissions only.

\subsection{Aerosol direct effect and the cloud-albedo aerosol indirect effect}

The aerosol direct radiative effect (DRE) and the cloudalbedo (first) aerosol indirect effect (AIE) in this study are calculated using an offline version of the Edwards and Slingo (ES) radiative transfer model (Edwards and Slingo, 1996) 
which has been used previously in other aerosol microphysics studies (Spracklen et al., 2011; Rap et al. 2013; Pierce et al. 2013; Scott et al. 2014). The ES radiative transfer model uses monthly mean cloud climatology and surface albedo, from the International Satellite Cloud Climatology Project (ISCCP) (Rossow and Schiffer, 1999), for the year 2000. Note that the land-use changes that lead to the changes in BVOC emissions explored in this paper may also lead to surface albedo and/or cloud changes; however, we do not explore these changes in this paper.

To investigate the changes in DRE, an offline version of the RADAER module from the Hadley Centre Global Environment Model (Bellouin et al., 2013) was adapted to calculate aerosol optical parameters from GEOS-Chem-TOMAS output. The refractive index for each size section is calculated as the volume-weighted mean refractive index of the components (given at $500 \mathrm{~nm}$ in Table A1 of Bellouin et al., 2011), including water. Water uptake is tracked explicitly in GEOSChem-TOMAS by using ISSOROPIA (Nenes et al., 1998). For computational efficiency, the optical properties (dimensionless asymmetry parameter, and scattering and absorption coefficients, in $\mathrm{m}^{2} \mathrm{~kg}^{-1}$ ) are then obtained from look-up tables of all realistic combinations of refractive index and Mie parameter (particle radius normalized to wavelength), as described by Bellouin et al. (2013). These aerosol optical properties were then included in monthly climatologies when running the offline ES radiative transfer model.

The cloud-albedo AIE is calculated by perturbing the effective radii of cloud droplets in the ES radiative transfer model. A control cloud droplet effective radius $\left(r_{\mathrm{e} 1}\right)$ of $10 \mu \mathrm{m}$ is assumed uniformly, to maintain consistency with the ISCCP derivation of liquid water path, and for each experiment a perturbed field of effective radii $\left(r_{\mathrm{e} 2}\right)$ for low- and mid-level (below $600 \mathrm{hPa}$ ) water clouds are calculated as in Eq. (1) using the control $\left(\mathrm{CDNC}_{1}\right)$ and perturbed $\left(\mathrm{CDNC}_{2}\right)$ fields of cloud droplet number concentration for each month.

$r_{\mathrm{e} 2}=r_{\mathrm{e} 1} \times\left[\frac{\mathrm{CDNC}_{1}}{\mathrm{CDNC}_{2}}\right]^{1 / 3}$

We calculate monthly mean CDNC using the aerosol size distributions predicted by GEOS-Chem-TOMAS and a mechanistic parameterization of cloud drop formation from Nenes and Seinfeld (2003), for a globally uniform updraft velocity of $0.2 \mathrm{~m} \mathrm{~s}^{-1}$. The assumption of a globally uniform updraft velocity is in itself a simplification and the AIE we calculate will be sensitive to the value used. Spracklen et al. (2011) and Pierce et al. (2013) found that assuming a base value of $0.2 \mathrm{~m} \mathrm{~s}^{-1}$ gave an AIE close to the mean AIE obtained when the globally uniform updraft velocity was varied between 0.1 and $0.5 \mathrm{~m} \mathrm{~s}^{-1}$. The cloud-albedo AIE is then calculated by comparing the perturbed (using $r_{\mathrm{e} 2}$ ) net radiative fluxes at the top of the atmosphere to a control simulation (using $r_{\mathrm{e} 1}$ ).

The DRE and cloud-albedo AIE are approximately additive, but to give a combined aerosol radiative effect, one must account for spatial overlap; therefore, a combined aerosol radiative effect is calculated by perturbing the cloud droplet effective radii and aerosol climatologies at the same time in the ES radiative transfer model, and comparing the net radiative fluxes to a control simulation in which neither is perturbed.

\section{Results}

\subsection{Changes to SOA formation rates}

Figure $2 \mathrm{a}$ and $\mathrm{b}$ show the mean millennial fixed-yield SOA formation from MEGAN BVOC emissions (monoterpenes, isoprene, and sesquiterpenes) and LPJ-GUESS BVOC emissions (monoterpenes and isoprene), respectively, in $\mathrm{mg} \mathrm{m}^{-2}$ day $^{-1}$ over the years $1000-2000$ and the base SOA yield assumptions. Figure $2 \mathrm{c}$ and e show the absolute and relative change in fixed-yield SOA formation from the same MEGAN BVOC emissions between 1000 and 2000 (year $2000-y e a r$ 1000), respectively. Figures $2 d$ and $f$ show the absolute and relative change in fixed-yield SOA formation from the same LPJ-GUESS BVOC emissions between 1000 and 2000 (year 2000-year 1000), respectively. An increase in SOA formation with time is represented in red, and a decrease in SOA formation in blue. Globally, the mean SOA formation from the MEGAN BVOC emissions decreases by 13.2 , and decreases by $18.9 \%$ from the LPJ-GUESS BVOC emissions. Regions such as central North America, eastern Australia, and southern South America show significant decreases, exceeding $75 \%$ in SOA formation from the MEGAN BVOC emissions. There are also regions such as India, and southeast Asia with increases of greater than $50 \%$ in SOA formation from the MEGAN BVOC emissions. These changes in emissions are largely due to millennial anthropogenic influences on BVOC emissions through landuse changes. In Fig. 2e, there are regions with large percent increases or decreases in SOA formation, such as western North America and northern Asia; however, the absolute change is negligible in these regions due to very low emissions. SOA formation from LPJ-GUESS BVOC emissions generally exhibits the same spatial pattern as MEGAN emissions. Where there are significant decreases/increases in BVOC emissions from 1000 to 2000, there are corresponding decreases/increases in SOA formation. Decreases/increases in SOA formation exceeding $50 \%$ would significantly decrease/increase the amount of low-volatility condensable organic material available to grow nanoparticles in the atmosphere. Therefore, changes in SOA formation of this magnitude could have an important anthropogenic aerosol effect on regional climates.

Changes over the past millennium in all three classes of terpenoid BVOCs (Fig. 1) combine to impact SOA formation in the atmosphere. Figure 3 shows the percent contribution to SOA formation by (a) isoprene, (b) monoterpene, and (c) sesquiterpene emissions using MEGAN BVOC emis- 

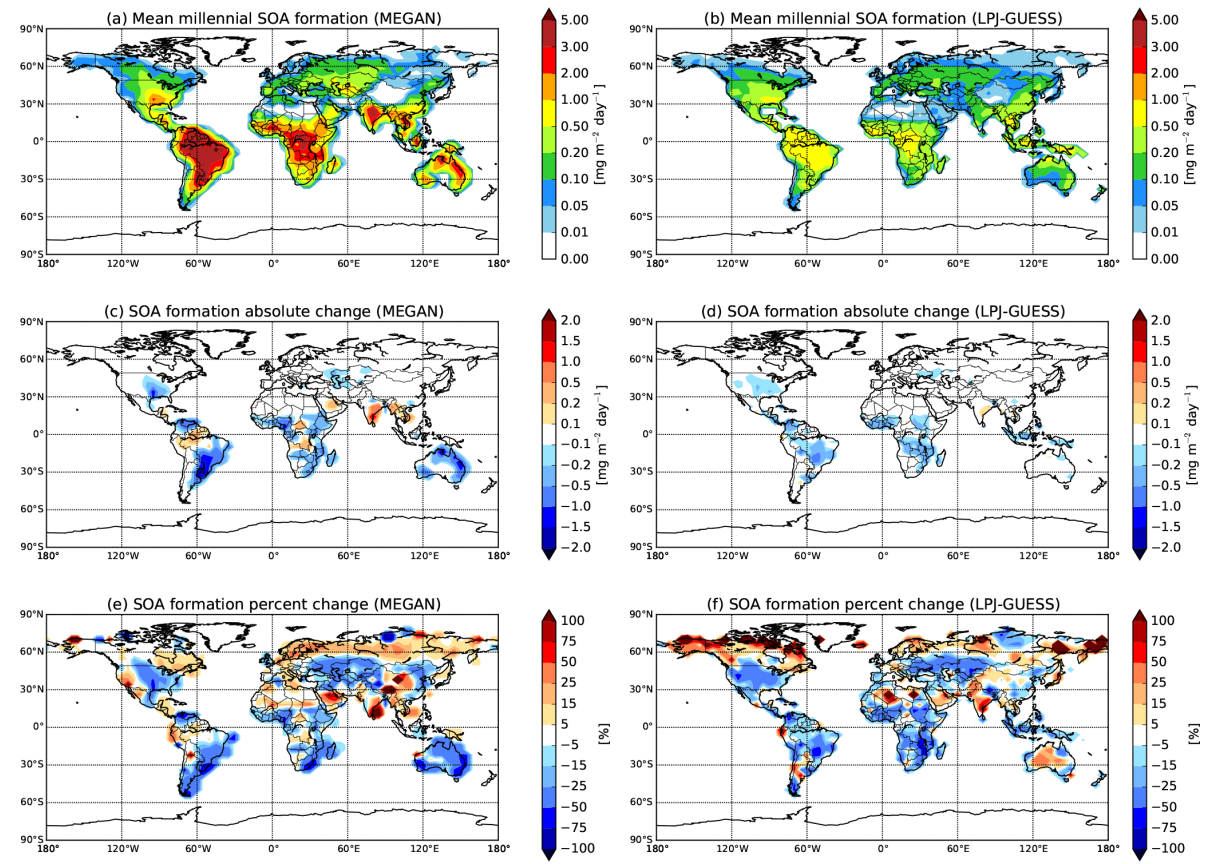

Figure 2. Mean millennial fixed-yield biogenic SOA formation from (a) MEGAN emissions and (b) LPJ-GUESS emissions between the periods 1000-2000 in $\mathrm{mg} \mathrm{m}^{-2} \mathrm{day}^{-1}$. Absolute change in fixed-yield biogenic SOA formation from averaged (c) MEGAN BVOC emissions (monoterpenes, isoprene, and sesquiterpenes) and (d) LPJ-GUESS BVOC emissions (monoterpenes and isoprene) between 1000 and 2000 in $\mathrm{mg} \mathrm{m}^{-2}$ day $^{-1}$. Relative change in fixed-yield biogenic SOA formation from averaged (e) MEGAN BVOC emissions (monoterpenes, isoprene, and sesquiterpenes) and (f) LPJ-GUESS BVOC emissions (monoterpenes and isoprene) between 1000 and 2000. An increase in SOA formation in (c), (d), (e), and (f) is represented in red, and a decrease in SOA formation in blue.

sions, averaged over the years 1000-2000. The area enclosed by the red contour represents regions with SOA formation rates greater than $5 \%$ of the maximum mean millennial SOA formation from emissions of all BVOCs (isoprene, monoterpenes, and sesquiterpenes). Isoprene (Fig. 3a) has the largest contribution to SOA formation with a global millennial mean contribution of $64 \%$. Regions where isoprene emissions have significant contributions to SOA formation (greater than $70 \%)$ are collocated with regions of highest total SOA formation (red contour). This shows that isoprene emissions are the predominant simulated source of global biogenic SOA formation, despite having the lowest SOA production yield of the three BVOCs. Some global models (e.g., D'Andrea et al., 2013; Lee et al., 2013) use monoterpene emissions as a representative $\mathrm{BVOC}$ for SOA formation rather than isoprene which may introduce errors in the spatial distribution and amount of biogenic SOA. Monoterpene emissions (Fig. 3b) contribute to $20 \%$ of global mean millennial SOA formation. Figure $3 \mathrm{~b}$ indicates that monoterpene emissions are the most important source of SOA in the Northern Hemisphere boreal-forested regions, with contributions exceeding $80 \%$. However, monoterpenes contribute less than $20 \%$ in regions with the highest total SOA formation. Sesquiterpene emissions represent the smallest global mean contribution to SOA formation at $16 \%$ over the past millennium. Unlike isoprene and monoterpene emissions that have clear regional importance, Fig. $3 \mathrm{c}$ indicates that sesquiterpene emissions tend to have a more uniform contribution to SOA formation across all vegetated regions, but rarely exceeding $20 \%$.

\subsection{Impact on aerosol number: changing BVOC emissions}

Table 2 summarizes the predicted global changes in particle number concentrations for all comparisons to follow. Figure 4 shows the change in (a) N3, (b) N10, (c) N40, and (d) N80 (number of particles with diameter greater than 3 , 10,40 , and $80 \mathrm{~nm}$, respectively) when changing MEGAN BVOC emissions from year 1000 to year 2000 with constant present-day anthropogenic emissions (2005) BE2.AE2.megBE1.AE2.meg). (We use $\mathrm{N} 40$ and $\mathrm{N} 80$ as proxies for the number of CCN-sized particles. However, the actual CCN and cloud droplet number concentrations depend on the maximum supersaturation reached in the cloud, which in turn depends on updraft velocities and particle concentrations. Comparing these two simulations isolates the effect of millennial changes in BVOC emissions on particle size distributions. Globally averaged, N3 and N10 increased by 2.3 and $1.5 \%$, respectively, whereas $\mathrm{N} 40$ and $\mathrm{N} 80$ decreased by 0.6 and $1.3 \%$, respectively (see Table 2 ). 
Table 2. Summary of global, annual mean percent changes in N3, N10, N40, and N80 (number of particles with diameter greater than $3,10,40$, and $80 \mathrm{~nm}$, respectively) when changing BVOC emissions from year 1000 to year 2000 using the MEGAN and LPJ-GUESS reconstructions. The values in brackets are the global maximum and minimum percent changes.

\begin{tabular}{cccccc|c}
\hline & \multicolumn{5}{c|}{ MEGAN } & LPJ-GUESS \\
\cline { 2 - 7 } & $\begin{array}{c}\text { BE2.AEO- } \\
\text { BE1.AEO }\end{array}$ & $\begin{array}{c}\text { BE2.AE2- } \\
\text { BE1.AE2 }\end{array}$ & $\begin{array}{c}\text { BE2.AEO.up- } \\
\text { BE1.AEO.up }\end{array}$ & $\begin{array}{c}\text { BE2.AE2.up- } \\
\text { BE1.AE2.up }\end{array}$ & $\begin{array}{c}\text { BE2.XSOA- } \\
\text { BE1.XSOA }\end{array}$ & $\begin{array}{c}\text { BE2.AEO.LPJ- } \\
\text { BE1.AEO.LPJ }\end{array}$ \\
\hline N3 & $\begin{array}{c}3.2 \% \\
(40 \%,-10 \%)\end{array}$ & $\begin{array}{c}2.3 \% \\
(49,-21 \%)\end{array}$ & $\begin{array}{c}4.6 \% \\
\text { N } \%,-10 \%)\end{array}$ & $\begin{array}{c}3.6 \% \\
(59 \%,-27 \%)\end{array}$ & $\begin{array}{c}(26 \%,-3 \%) \\
(63 \%,-17 \%)\end{array}$ & $5.9 \%$ \\
\hline N10 & $1.9 \%$ & $1.5 \%$ & $2.6 \%$ & $2.6 \%$ & $1.2 \%$ & $3.5 \%$ \\
& $(38 \%,-25 \%)$ & $(29 \%,-13 \%)$ & $(40 \%,-29 \%)$ & $(34 \%,-18 \%)$ & $(17 \%,-2 \%)$ & $(36 \%,-13 \%)$ \\
\hline N40 & $0.4 \%$ & $-0.6 \%$ & $1.1 \%$ & $-0.0 \%$ & $0.3 \%$ & $-0.1 \%$ \\
& $(28 \%,-23 \%)$ & $(18 \%,-42 \%)$ & $(45 \%,-44 \%)$ & $(20 \%,-41 \%)$ & $(8 \%,-14 \%)$ & $(24 \%,-28 \%)$ \\
\hline N80 & $-0.6 \%$ & $-1.3 \%$ & $0.0 \%$ & $-1.2 \%$ & $-0.3 \%$ & $-1.8 \%$ \\
& $(20 \%,-28 \%)$ & $(21 \%,-43 \%)$ & $(33 \%,-24 \%)$ & $(25 \%,-40 \%)$ & $(5 \%,-21 \%)$ & $(34 \%,-36 \%)$ \\
\hline
\end{tabular}

(a) Contribution to SOA formation from isoprene

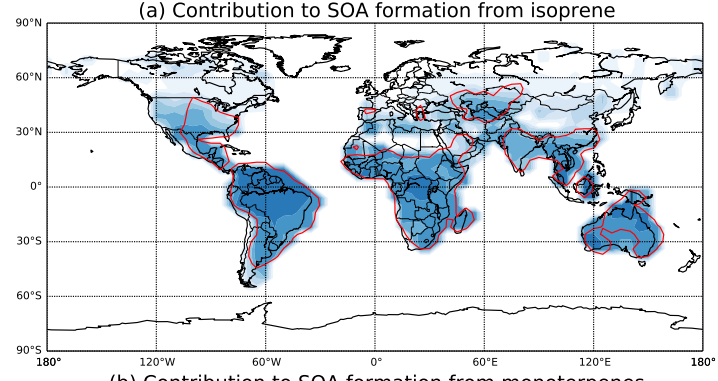

(b) Contribution to SOA formation from monoterpenes

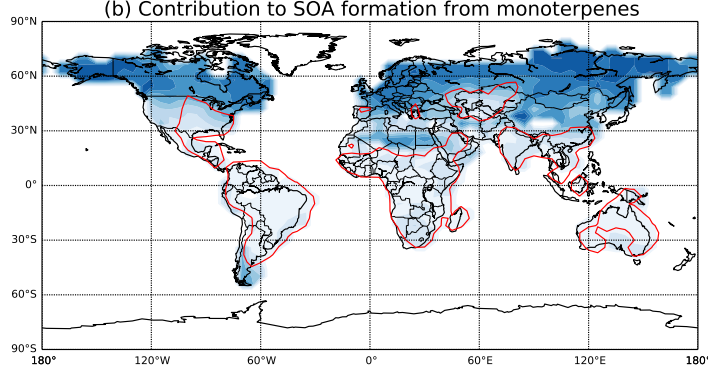

(c) Contribution to SOA formation from sesquiterpenes
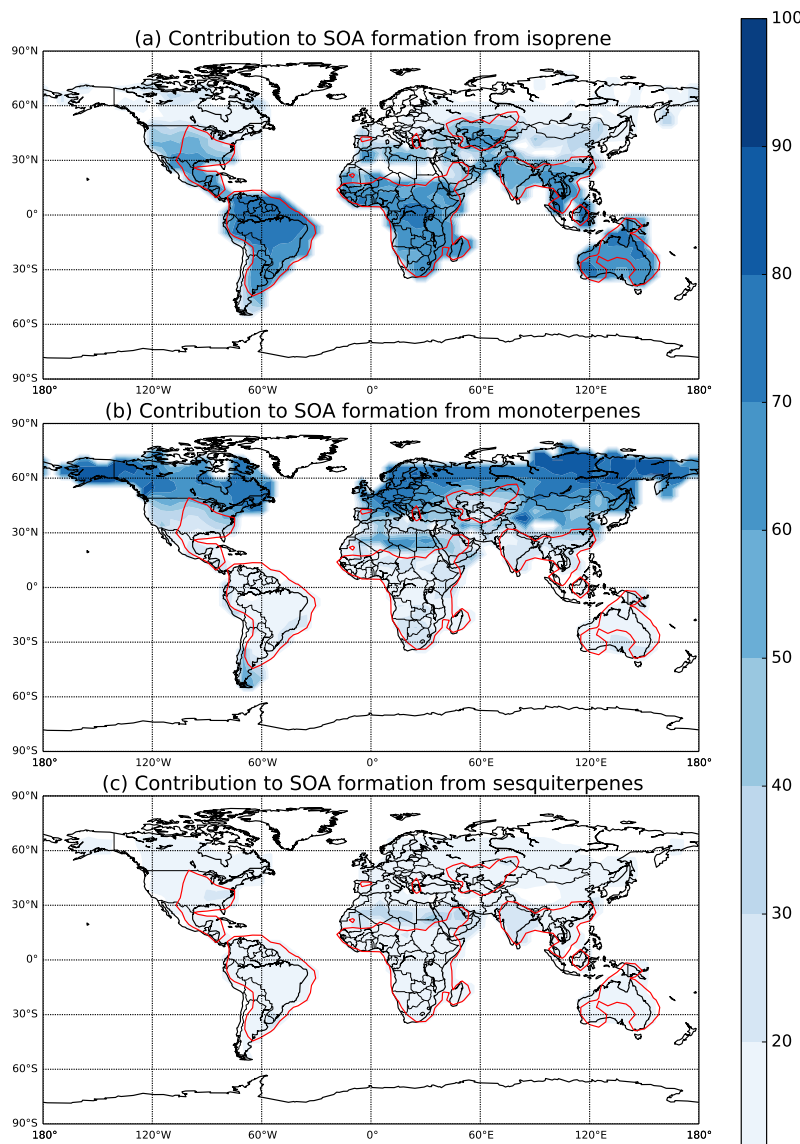

60

Figure 3. Percent contribution to SOA formation by (a) isoprene, (b) monoterpene, and (c) sesquiterpene emissions from the MEGAN reconstruction, averaged over the years 1000-2000. The area enclosed by the red contour represents greater than $5 \%$ of the maximum mean millennial SOA formation from emissions of BVOCs (isoprene, monoterpenes, and sesquiterpenes).
There are decreases in N80 exceeding $25 \%$ in regions such as southern South America, southern Africa, southeastern North America, and Australia. These regions coincide with regions of significant decrease in isoprene emissions (Fig. 1) and SOA formation (Fig. 2). The relationship between the decrease in isoprene emissions and SOA formation with the decrease in $\mathrm{N} 80$ and increase in N3 and N10 can be explained through microphysical feedback mechanisms. Firstly, the decrease in total isoprene emissions in these regions causes a decrease in SOA formation as explained in Sect. 4.1. With decreases in SOA formation, ultrafine particle growth decreases due to the reduction in available condensable material. This can be seen in Fig. $4 a$ and $b$ where increases in N3 and N10 are collocated. This suppression of ultrafine particle growth limits the number of particles that can grow to $\mathrm{CCN}$ sizes, hence decreasing $\mathrm{N} 80$ in these regions. A reduction in the number of $\mathrm{N} 80$ reduces the coagulation sink of smaller particles, and N3 and N10 increase. This can be seen in Fig. 4, where regions of increasing N3 and N10 coincide with regions of decreasing $\mathrm{N} 40$ and $\mathrm{N} 80$. Throughout these regions, N3 and N10 increases exceed $25 \%$, and decreases in $\mathrm{N} 40$ and $\mathrm{N} 80$ exceed $25 \%$. These are significant changes in $\mathrm{CCN}$ concentrations (N40 and $\mathrm{N} 80$ ) in these regions due largely to changes in BVOCs due to anthropogenic landuse changes. With significant decreases in $\mathrm{N} 40$ and N80, the condensation sink for sulfuric acid $\left(\mathrm{H}_{2} \mathrm{SO}_{4}\right)$ and coagulation sink for ultrafine particles also decreases. This increases the survival probability of ultrafine particles and hence increases N3 and N10. Secondly, with a decrease in SOA formation and a decrease in ultrafine particle growth, the concentration of sulfuric acid $\left(\mathrm{H}_{2} \mathrm{SO}_{4}\right)$ vapor increases in these regions due to a decrease in the condensation sink. This increases nucleation due to the strong dependence on $\mathrm{H}_{2} \mathrm{SO}_{4}$ vapor concentrations. Therefore, increased nucleation increases the number of freshly nucleated particles and N3. 

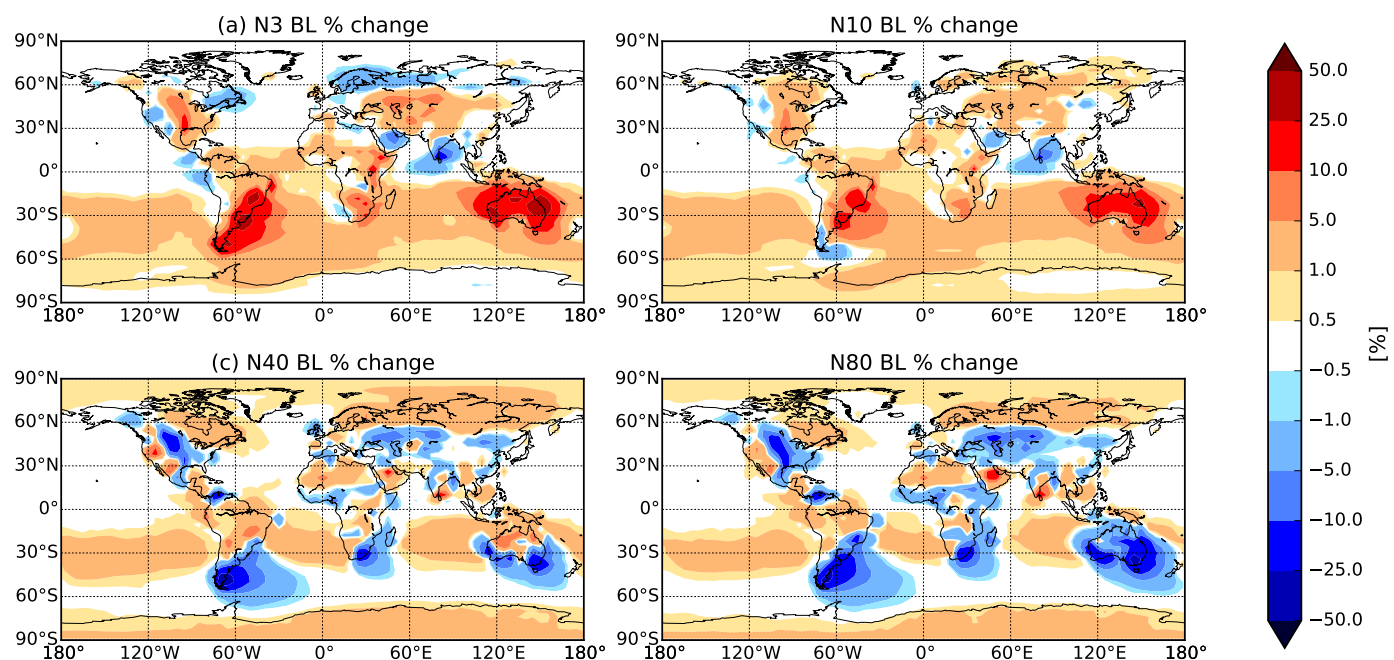

Figure 4. Percentage change in annually averaged boundary layer (a) N3, (b) N10, (c) N40, and (d) N80 (number of particles with diameter greater than 3,10,40, and $80 \mathrm{~nm}$, respectively) when changing MEGAN BVOC emissions from year 1000 to year 2000 with constant present-day anthropogenic emissions (2005) (BE2.AE2.meg-BE1.AE2.meg). Globally averaged, N3 and N10 increased by 2.3 and $1.5 \%$, respectively, whereas N40 and N80 decreased by 0.6 and $1.3 \%$, respectively (see Table 2). An increase in particle number concentration is represented in red, and a decrease in blue.

There are also increases in N80 over oceanic regions downwind of regions with significant decreases in N80. This is caused by the increases in N3 and N10 over land. When the air mass is advected over the ocean, the surplus of small particles are able to grow via condensation to $\mathrm{CCN}$ sizes. Figure 5 shows the zonal-mean percentage change in (a) N3, (b) N10, (c) N40, and (d) N80 when changing MEGAN BVOC emissions from year 1000 to year 2000 with constant present-day anthropogenic emissions (2005) (BE2.AE2.meg-BE1.AE2.meg). Figure 5 indicates that the difference in number concentrations between the two simulations varies with height. The difference in $\mathrm{N} 3$ and N10 between the simulations with height generally remains positive above the boundary layer (BL), with increases exceeding $5 \%$ in the southern mid-latitudes in oceanic and deforested regions particularly. However, the differences in N40 and N80 between the simulations reverse sign with height in the mid-latitudes, most dramatically in the Southern Hemisphere such that there are more particles in the BE2.AE2.meg simulation. When CCN-sized particles are removed through wet deposition during vertical advection, there are more ultrafine particles to grow to $\mathrm{CCN}$ sizes and replace the lost $\mathrm{CCN}$ in the BE2.AE2.meg simulation than in BE1.AE2.meg. This feedback leads to the change in sign with height for N40 and N80. This reversal in the change in particle number concentrations has implications for radiative forcing and will be discussed in Sect. 4.3.

Figure 6 shows the change in (a) N3, (b) N10, (c) N40, and (d) N80 when changing MEGAN BVOC emissions from year 1000 to year 2000 with anthropogenic emissions turned off (BE2.AEO.meg-BE1.AEO.meg). Globally aver- aged, N3, N10, and N40 increased by 3.2, 1.9, and $0.4 \%$, respectively, whereas N80 decreased by $0.6 \%$ (see Table 2). Similar to the previous case, globally averaged N3 and N10 increased over the past millennium. However, contrary to the previous case, with anthropogenic emissions turned off, globally averaged N40 also increased. The spatial patterns in globally averaged number of CCN-sized particles (N80) in this simulation reflected the same decreasing trend as shown in Fig. 4. In Fig. 6, the regions of increasing N3 and N10 coincide with regions of decreasing $\mathrm{N} 40$ and N80, following the same spatial pattern as in Fig. 4. Thus, the presence of anthropogenic aerosols does not qualitatively change the fractional response of the aerosol size distribution to millennial changes in BVOCs.

The microphysical feedback mechanisms in this comparison (BE2.AEO.meg-BE1.AEO.meg) are the same as the previous comparison (BE2.AE2.meg-BE1.AE2.meg); however, the magnitude of the changes in particle number concentrations due to BVOCs differs. With anthropogenic emissions turned off to simulate pre-industrial conditions, changes in number concentrations of particles in all size ranges are shifted towards more positive changes than the simulation with present-day anthropogenic emissions. This is caused by the difference in total particle number concentrations and the mean size of the particles. As seen in Fig. 7, presentday anthropogenic conditions have more than 4 times more particles by number than the pre-industrial conditions and the mean diameter is at smaller sizes. The mean diameter in the simulation with present-day anthropogenic conditions is $30.6 \mathrm{~nm}$, whereas the simulation with pre-industrial anthropogenic conditions had a mean diameter of $52.1 \mathrm{~nm}$. There- 

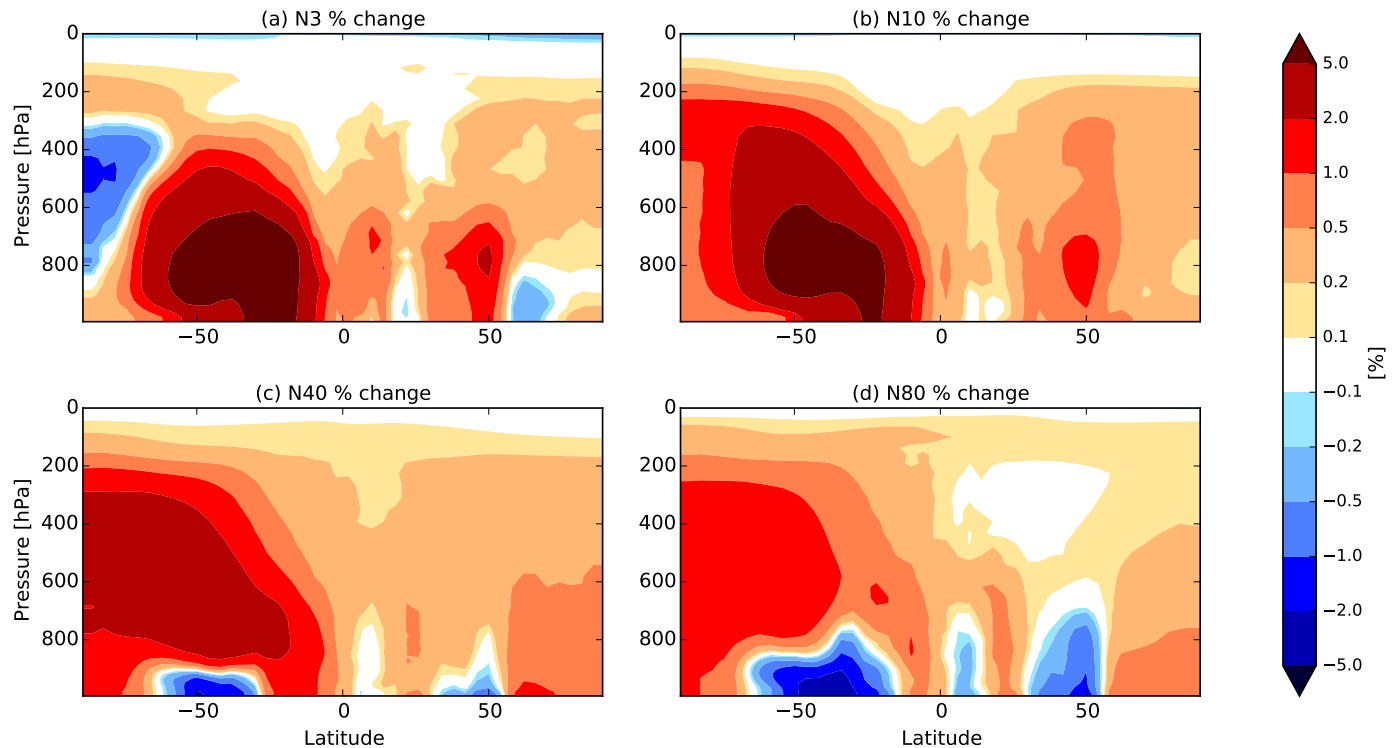

Figure 5. Zonal-mean annual-average percentage change in (a) N3, (b) N10, (c) N40, and (d) N80 when changing MEGAN BVOC emissions from year 1000 to year 2000 with constant present-day anthropogenic emissions (2005) (BE2.AE2.meg-BE1.AE2.meg). An increase in particle number concentration is represented in red, and a decrease in blue.
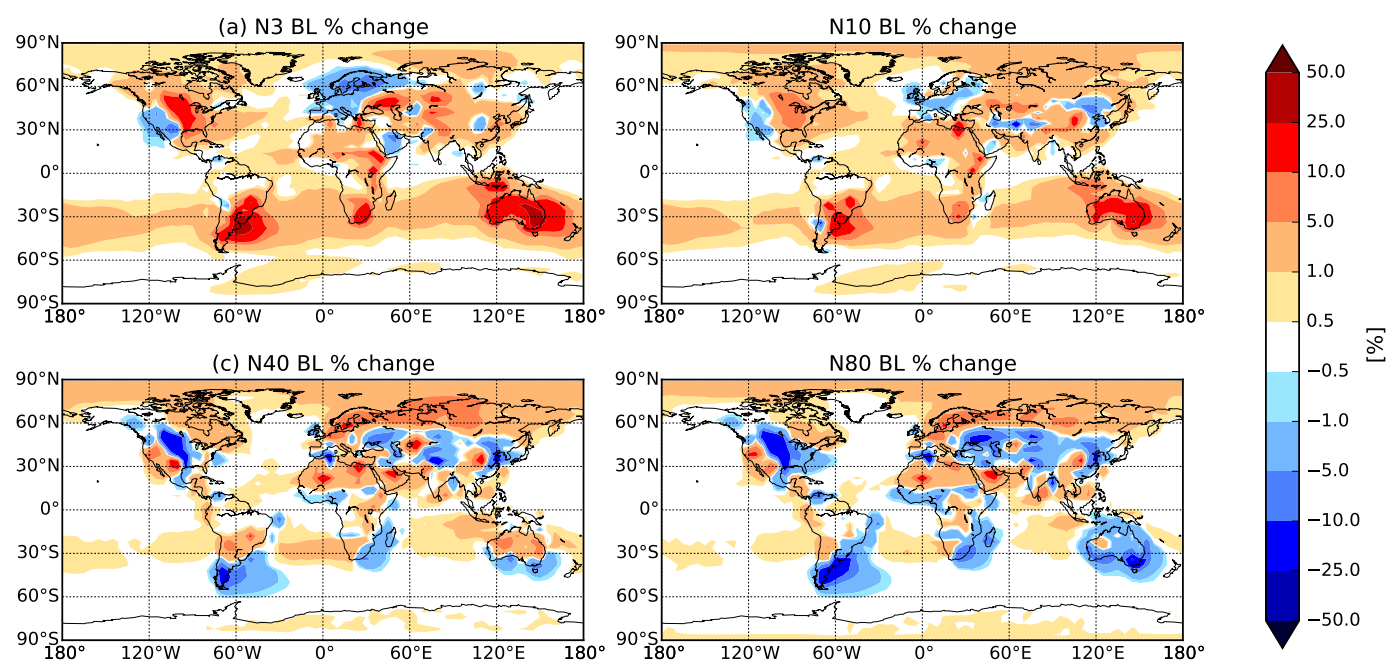

Figure 6. Percentage change in annually averaged boundary layer (a) N3, (b) N10, (c) N40, and (d) N80 when changing MEGAN BVOC emissions from year 1000 to year 2000 with anthropogenic emissions off (BE2.AEO.meg-BE1.AEO.meg). Globally averaged, N3, N10, and $\mathrm{N} 40$ increased by 3.2, 1.9, and $0.4 \%$, respectively, whereas N80 decreased by $0.6 \%$ (see Table 2). An increase in particle number concentration is represented in red, and a decrease in blue.

fore, there are an increased number of ultrafine particles competing for condensation of SOA and growth to $\mathrm{CCN}$ sizes in the simulations with anthropogenic emissions on, and the particles in these simulations are (on average) smaller and further from $\mathrm{CCN}$ sizes than simulations with anthropogenic emissions off. Thus, ultrafine particles grow to $\mathrm{CCN}$ sizes more efficiently in the simulations with anthropogenic emissions turned off and are more susceptible to BVOC emission changes because there are fewer particles competing for con- densable material and the mean size is larger. The fractional changes in N3 are larger in the cases with anthropogenic emissions off because there are fewer particles overall. Thus, there is a smaller increase in N3 and larger decrease in N80 than with anthropogenic emissions turned off.

The effect on particle numbers by changing anthropogenic emissions under fixed BVOC emissions was also investigated (not shown). The globally averaged change in N3, $\mathrm{N} 10, \mathrm{~N} 40$, and N80 when changing anthropogenic emissions 


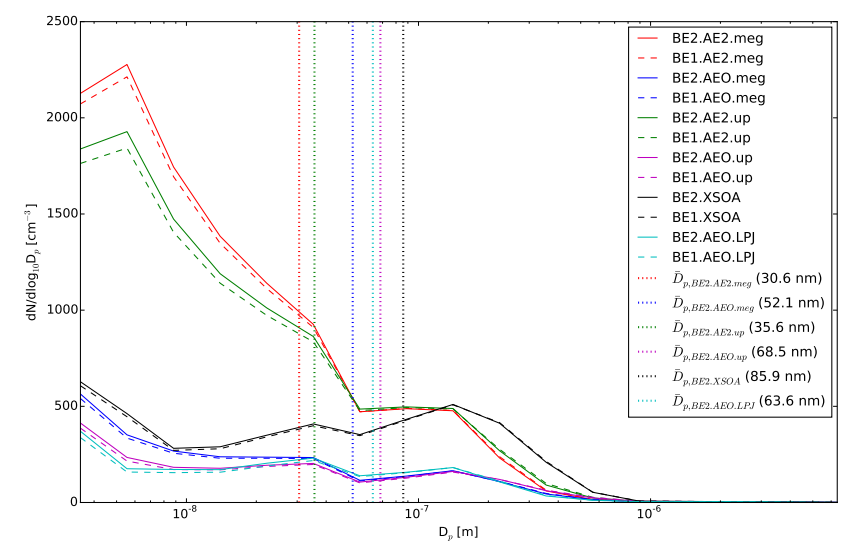

Figure 7. Simulated global boundary layer annual-mean particle number size distributions for the simulations outlined in Table 1. The vertical dotted lines represent the mean diameter for the simulations using year 2000 biogenic emissions (BE2.AE2.meg, BE2.AEO.meg, BE2.AE2.up, BE2.AEO.up, BE2.XSOA, and BE2.AEO.LPJ).

from pre-industrial (off) to present-day (2005) with constant present-day BVOC emissions (average biogenic emissions from 1980-1990) (BE2.AE2.meg-BE2.AEO.meg) increased by $382,339,212$, and $162 \%$, respectively. These global sensitivities to anthropogenic emissions changed only modestly when biogenic emissions from 1000 were used (BE1.AE2.meg-BE1.AEO.meg): globally averaged $\mathrm{N} 3, \mathrm{~N} 10, \mathrm{~N} 40$, and $\mathrm{N} 80$ all increased by $386,341,215$, and $164 \%$, respectively. The global millennial change in particles due to BVOC changes is small compared to the change in anthropogenic emissions; however, the change in particles due to changes in BVOC is still non-trivial, and we will discuss this further when discussing radiative forcing. This emphasizes the importance of accurately quantifying the aerosols in the pre-industrial reference state used for radiative forcing calculations (Carslaw et al., 2013)

The sensitivity of particle numbers to upper bounds on SOA yields was also investigated. The fixed SOA yields used in the standard simulations $(3,10$, and $20 \%$ for isoprene, monoterpenes, and sesquiterpenes, respectively) were increased to 10,20 , and $40 \%$ for isoprene, monoterpenes, and sesquiterpenes, respectively, in the upper-bound simulations (BE2.AEO.up, BE1.AEO.up, BE2.AE2.up, and BE1.AE2.up). When using the upper-bound SOA yields and changing MEGAN BVOC emissions from year 1000 to year 2000 with anthropogenic emissions turned off (BE2.AEO.up-BE1.AEO.up), globally averaged N3, N10, $\mathrm{N} 40$, and $\mathrm{N} 80$ increased by $4.6,2.6,1.1$, and $0.0 \%$, respectively (see Table 2). The spatial distribution of the global changes in particle number concentrations are similar to those of Fig. 4, with modest increases in magnitude. Even with more than a doubling of the SOA yields from all three terpenoid species, the change in particle number responded with less than a doubling due to microphysical dampening. This has also been observed in other global aerosol microphysics models (e.g., Scott et al., 2014). With an increase in SOA yields, there is a corresponding increase in the amount of condensable material available for particle growth. However, due to the nonlinear balance between condensational growth and coagulational scavenging, increases in particle number concentrations do not scale linearly with increases in SOA formation.

This microphysical feedback was also seen when using upper-bound SOA yields while changing MEGAN BVOC emissions from year 1000 to year 2000 with present-day anthropogenic emissions (2005) (BE2.AE2.up-BE1.AE2.up). Globally averaged, N3 and N10 increased by 3.6 and $2.6 \%$, respectively, whereas $\mathrm{N} 40$ and $\mathrm{N} 80$ decreased by 0.0 and $1.2 \%$, respectively (see Table 2). This comparison showed the same spatial patterns as the standard yield comparison of Fig. 6 with modest increases in magnitude similar to the simulations with anthropogenic emissions off. The nonlinear impact on global particle number concentrations due to microphysical dampening was also observed in this comparison. Therefore, due to the similarity of the upper-bound SOA yield simulations to the standard SOA yield simulations, we have not included these in the figures. However, the SOA yields will also likely not remain constant since they will change with varying conditions such as aerosol loading or $\mathrm{NO}_{\mathrm{x}}$ concentrations.

The sensitivity of particle numbers to historical changes in BVOC emissions with the inclusion of an additional $100 \mathrm{Tg} \mathrm{yr}^{-1}$ of anthropogenically enhanced SOA as per D'Andrea et al. (2013) was also investigated. The additional SOA used here may be SOA from BVOCs enhanced by anthropogenic pollution; however, we leave this additional SOA source constant for both year 1000 and year 2000 biogenic emission simulations as an additional sensitivity study. Figure 8 shows the change in (a) N3, (b) N10, (c) N40, and (d) N80 when changing MEGAN BVOC emissions from year 1000 to year 2000 with constant present-day anthropogenic emissions including the additional $100 \mathrm{Tg} \mathrm{SOA} \mathrm{yr}^{-1}$ (BE2.XSOA-BE1.XSOA). Globally averaged, N3, N10, and N40 increased by $1.9,1.2$, and $0.3 \%$, respectively, whereas N80 decreased by $0.3 \%$ (see Table 2). The changes in particle number concentrations with the additional $100 \mathrm{Tg}$ (SOA) $\mathrm{yr}^{-1}$ are lower in magnitude than the standard case (BE2.AE2.meg-BE1.AE2.meg). With the inclusion of the additional SOA, there is a large increase in the amount of condensable material available for particle growth. Therefore, the smallest particles are able to grow more efficiently via condensation to larger sizes. This can be seen in Fig. 7 where the mean diameter for the simulation BE2.XSOA is $85.9 \mathrm{~nm}$ as opposed to $30.6 \mathrm{~nm}$ for BE2.AE2.meg. However, the change in SOA from changes in BVOC emissions is an order of magnitude lower than the additional anthropogenically enhanced SOA; therefore, the global changes in particle number concentrations when comparing the additional 
SOA cases (BE2.XSOA-BE1.XSOA) to the standard cases (BE2.AE2.meg-BE1.AE2.meg) are lower in magnitude (see Table 2).

Figure 9 shows the change in (a) N3, (b) N10, (c) N40, and (d) N80 when changing LPJ-GUESS BVOC emissions from year 1000 to year 2000 with anthropogenic emissions off (BE2.AEO.LPJ-BE1.AEO.LPJ), providing an estimate for the aerosol changes when using an independent estimate of BVOC changes. Globally averaged, N3 and N10 increased by 5.9 and $3.5 \%$, respectively, whereas $\mathrm{N} 40$ and N80 decreased by 0.1 and $1.8 \%$, respectively (see Table 2). The magnitude of the changes in N3 and N80 with the LPJGUESS simulations are the highest of all the simulations. This is due in part to the spatial variability in the LPJ-GUESS emission inventory when compared to the MEGAN emission inventory, as well as lower total emissions. Similar to the comparable simulations using the MEGAN emissions (BE2.AEO.meg-BE1.AEO.meg; Fig. 6), there are increases in N3 over central North America, southern South America, eastern Australia, and central Eurasia exceeding $25 \%$. These regions correspond to regions of decreased BVOC emissions over the past millennium, which leads to decreases in SOA formation and increases in N3 (due to the deficit of condensable material available to grow the smallest particles to $\mathrm{CCN}$ sizes). The same regions with significant increases in $\mathrm{N} 3$ also correspond to regions of significant decreases in $\mathrm{CCN}$-sized particles. However, there are regions where the MEGAN simulations and the LPJ-GUESS simulations differ. Even though LPJ-GUESS emits less BVOC emissions globally than MEGAN, the LPJ-GUESS simulations indicate higher-magnitude increases in N3 in the Northern Hemisphere than MEGAN. This is due to LPJ-GUESS emitting relatively more BVOCs in the northern boreal-forested regions than MEGAN (largely due to the different emission factors assumed for vegetation types and the treatment of the $\mathrm{CO}_{2}$ response of the two emission models), and therefore increased SOA formation. This is reflected in the global mean size distribution (Fig. 7) where it can be seen that BE2.AEO.LPJ has fewer small particles than BE2.AEO.meg, confirmed by a larger mean diameter at $63.6 \mathrm{~nm}$ as opposed to $52.1 \mathrm{~nm}$ for BE2.AEO.meg. Overall, the percent change in N80 between the LPJ-GUESS and MEGAN simulations have a correlation coefficient of 0.49 . The previously mentioned regional differences between the two BVOC reconstructions are a source of uncertainty, but the global percent change in N80 both follow the same trend (Table 2). This indicates that anthropogenic land-use changes over the past millennium have decreased the number of $\mathrm{CCN}$-sized particles globally through changes in BVOC emissions, with regional changes in $\mathrm{CCN}$-sized particles ranging from -25 to $25 \%$.

The distribution of changes across all grid boxes in N3, $\mathrm{N} 10, \mathrm{~N} 40$, and $\mathrm{N} 80$ for all simulations are summarized in Fig. 10 (see Table 2 for specific values). Plotted are the global percent changes in $\mathrm{N} 3, \mathrm{~N} 10, \mathrm{~N} 40$, and $\mathrm{N} 80$ for bio- genic emissions from 1000 to 2000 on a logarithmic scale. For all of the simulation comparisons, there is an increase in mean N3 and a decrease in mean N80. This is due mainly to the decrease in isoprene emissions over the past millennium, predominantly influenced by land-use changes. However, the majority of the changes globally are very close to zero (as can be seen by the size of the interquartile range on all plots). This is caused by minute changes in number concentrations over open ocean regions. Also, there is significant variability in the magnitude of the changes in all simulations as can be seen by the extent of the maximum and minimum changes in particle number concentrations. This indicates that caution must be taken when interpreting global mean values, as regional changes are of importance.

\subsection{Aerosol direct and indirect radiative effects}

Figure 11 shows the annual mean radiative effect due to changes in BVOC emissions between year 1000 and year 2000 (see Table 3 for summarization). Figure 11a shows the DRE due to changing BVOC emissions between year 1000 and year 2000 with MEGAN BVOC emissions and anthropogenic emissions off (BE2.AEO.meg-BE1.AEO.meg), giving a global annual mean DRE of $+0.065 \mathrm{~W} \mathrm{~m}^{-2}$. While this global-mean DRE from biogenic emissions changes is smaller in magnitude than estimated anthropogenic direct radiative forcings (e.g., estimates of -0.85 to $+0.15 \mathrm{~W} \mathrm{~m}^{-2}$ in the most recent IPCC report, Boucher et al. 2013), the DRE from biogenic emissions changes may be much larger regionally. Throughout most oceanic regions, the DRE is small $\left(<0.05 \mathrm{~W} \mathrm{~m}^{-2}\right)$; however, over land there are large regions experiencing a DRE greater than $+0.5 \mathrm{~W} \mathrm{~m}^{-2}$ (e.g., southeastern South America, southern Africa, Australia, and southeastern North America). This is caused by significant decreases in N80 (as seen in Fig. 6) and the total mass of particles (not shown), which decreases the scattering of incoming solar radiation. There are regions of negative radiative forcing (e.g., India), which are associated with increases in N80 and total aerosol mass due to increased BVOC emissions from the anthropogenic introduction of high BVOCemitting plants and cropland. There is a band of positive radiative forcing in the Southern Hemisphere, which is associated with mid-latitude westerlies transporting accumulationmode particles over oceanic regions.

Figure $11 \mathrm{~b}$ shows the DRE due to changing BVOC emissions between year 1000 and year 2000 with LPJGUESS BVOC emissions and anthropogenic emissions off (BE2.AEO.LPJ-BE1.AEO.LPJ), giving a global annual mean DRE of $+0.022 \mathrm{~W} \mathrm{~m}^{-2}$. Similar to Fig. 11a, the DRE is very small $\left(<0.05 \mathrm{~W} \mathrm{~m}^{-2}\right)$ over most of the globe, in particular oceanic regions. However, over BVOC source regions, the DRE exceeds $+0.3 \mathrm{~W} \mathrm{~m}^{-2}$ due to decrease in isoprene emissions and N80 in those regions. The DRE obtained using emissions from LPJ-GUESS is spatially similar to that obtained with the MEGAN emissions, albeit lower in magni- 

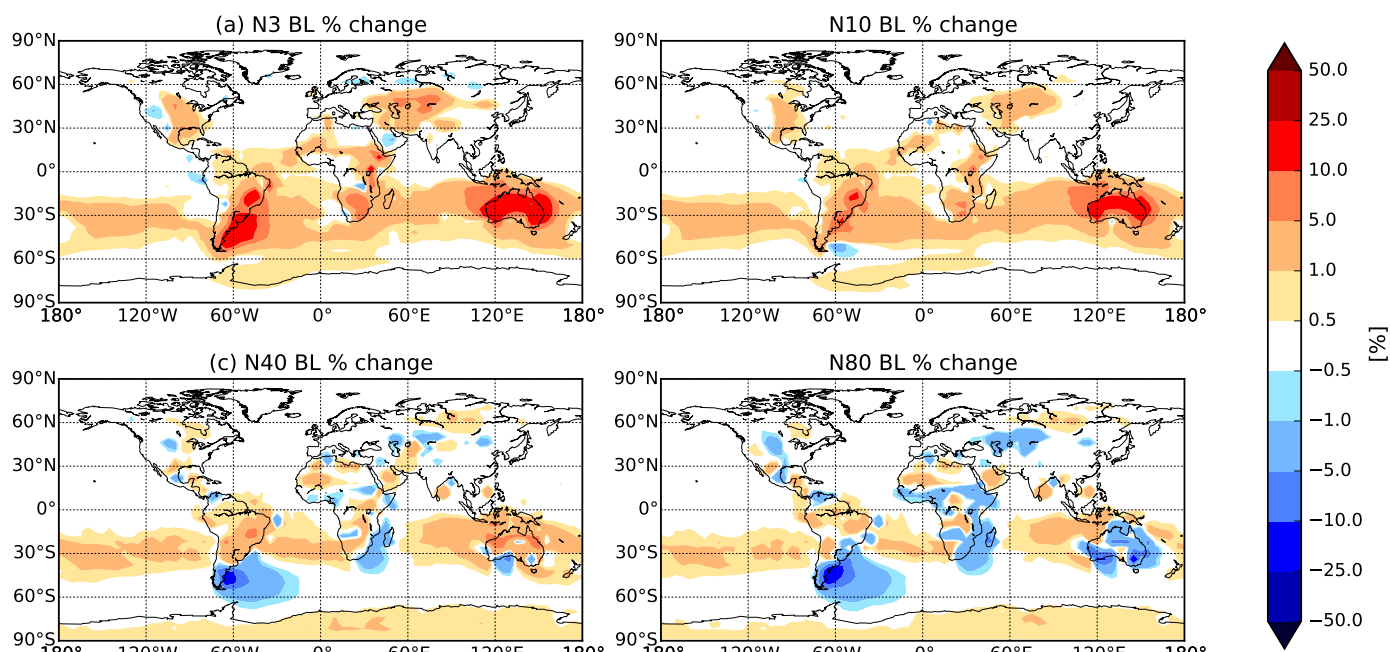

Figure 8. Percentage change in annually averaged boundary layer (a) N3, (b) N10, (c) N40, and (d) N80 when changing MEGAN BVOC emissions from year 1000 to year 2000 with constant present-day anthropogenic emissions (2005) including an additional $100 \mathrm{Tg} \mathrm{SOA} \mathrm{yr}^{-1}$ as per D'Andrea et al. (2013) (BE2.XSOA-BE1.XSOA). Globally averaged, N3, N10, and N40 increased by 1.9, 1.2, and $0.3 \%$, respectively, whereas N80 decreased by $0.3 \%$ (see Table 2). An increase in particle number concentration is represented in red, and a decrease in blue.
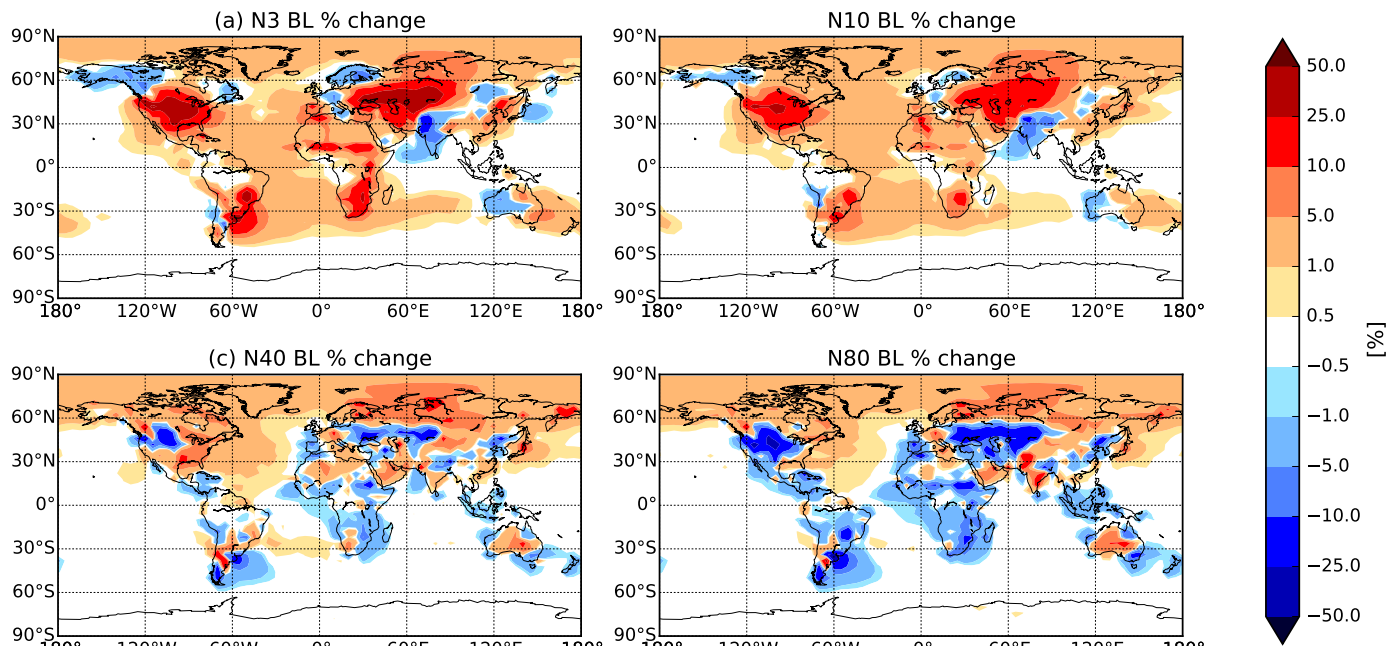

Figure 9. Percentage change in annually averaged boundary layer (a) N3, (b) N10, (c) N40, and (d) N80 when changing LPJ-GUESS BVOC emissions from year 1000 to year 2000 with anthropogenic emissions off (BE2.AEO.LPJ-BE1.AEO.LPJ). Globally averaged, N3 and N10 increased by 5.9 and $3.5 \%$, respectively, whereas N40 and N80 decreased by 0.1 and $1.8 \%$, respectively (see Table 2). An increase in particle number concentration is represented in red, and a decrease in blue.

tude (due to smaller emissions changes). However, there is a large difference in DRE between MEGAN and LPJ-GUESS over Australia. This is due to a decrease in emissions from MEGAN between year 1000 and year 2000, resulting in a decrease in SOA formation and leading to a strong positive DRE. However, there are smaller magnitude changes in emissions from LPJ-GUESS, which are due to a combination of inland increases and coastal decreases (mainly caused by changes in isoprene emissions), leading to a combination of increases and decreases in N80 over Australia.
Figure 11c shows the cloud-albedo AIE due to changing BVOC emissions between year 1000 and year 2000 with MEGAN BVOC emissions and anthropogenic emissions off (BE2.AEO.meg-BE1.AEO.meg), giving a global annual mean cloud-albedo AIE of $-0.020 \mathrm{~W} \mathrm{~m}^{-2}$. Similar to DRE above, the global-mean AIE from biogenic emissions changes is smaller than estimated aerosol indirect forcings from anthropogenic aerosols (e.g., -0.3 to $-1.8 \mathrm{~W} \mathrm{~m}^{-2}$ in IPCC AR4, Forster et al., 2007), but again the regional AIE from biogenic emissions changes can be significantly larger than the mean. There is a band of negative radia- 
Table 3. Summary of global, annual mean changes in aerosol direct radiative effect (DRE), first aerosol indirect effect (AIE), and combined radiative effect in $\mathrm{W} \mathrm{m}^{-2}$ when changing BVOC emissions from year 1000 to year 2000 using the MEGAN and LPJ-GUESS reconstructions. The values in brackets are the global maximum and minimum changes, respectively.

\begin{tabular}{lccccc|c}
\hline & \multicolumn{5}{c}{ MEGAN } & LPJ-GUESS \\
\cline { 2 - 6 } & $\begin{array}{c}\text { BE2.AEO- } \\
\text { BE1.AEO }\end{array}$ & $\begin{array}{c}\text { BE2.AE2- } \\
\text { BE1.AE2 }\end{array}$ & $\begin{array}{c}\text { BE2.AEO.up- } \\
\text { BE1.AEO.up }\end{array}$ & $\begin{array}{c}\text { BE2.AE2.up- } \\
\text { BE1.AE2.up }\end{array}$ & $\begin{array}{c}\text { BE2.XSOA- } \\
\text { BE1.XSOA }\end{array}$ & $\begin{array}{c}\text { BE2.AEO.LPJ- } \\
\text { BE1.AEO.LPJ }\end{array}$ \\
\hline $\mathrm{DRE}$ & +0.065 & +0.050 & +0.129 & +0.163 & +0.052 & +0.022 \\
{$\left[\mathrm{~W} \mathrm{~m}^{-2}\right]$} & $(-0.305,+1.008)$ & $(-0.394,+1.005)$ & $(-0.521,+1.806)$ & $(-0.934,+2.020)$ & $(-0.377,+0.985)$ & $(-0.059,+0.381)$ \\
\hline $\mathrm{AlE}^{*}$ & -0.020 & -0.035 & -0.035 & -0.056 & -0.025 & -0.008 \\
{$\left[\mathrm{~W} \mathrm{~m}^{-2}\right]$} & $(-0.175,+0.201)$ & $(-0.262,+0.406)$ & $(-0.291,+0.212)$ & $(-0.369,+0.154)$ & $(-0.288,+0.108)$ & $(-0.156,+0.285)$ \\
\hline $\begin{array}{l}\text { Combined radiative } \\
\text { effect* }\end{array}$ & +0.049 & +0.022 & +0.101 & +0.118 & +0.032 & +0.015 \\
\hline
\end{tabular}

* Cloud drop number concentrations were calculated using a globally uniform updraft velocity of $0.2 \mathrm{~m} \mathrm{~s}^{-1}$.
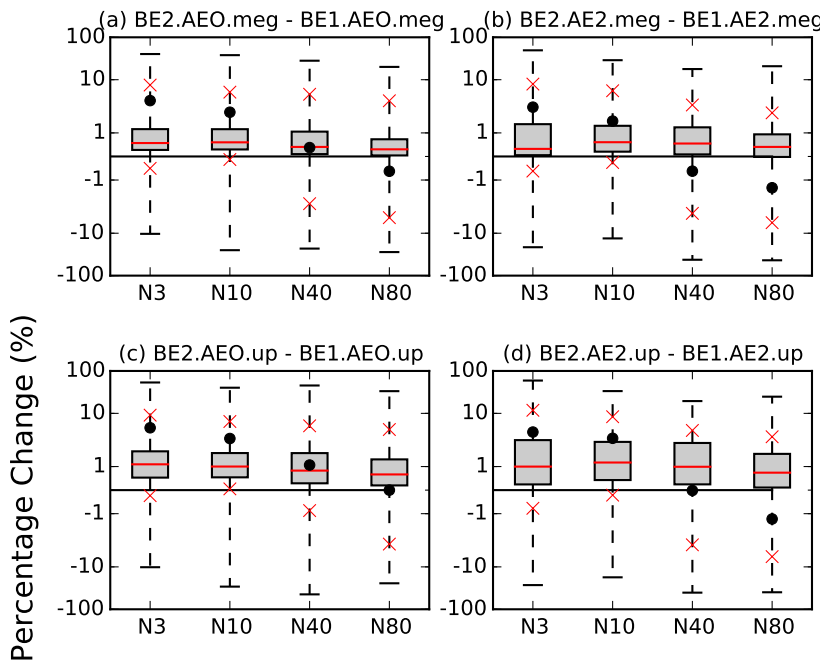

(d) BE2.AE2.up - BE1.AE2.up
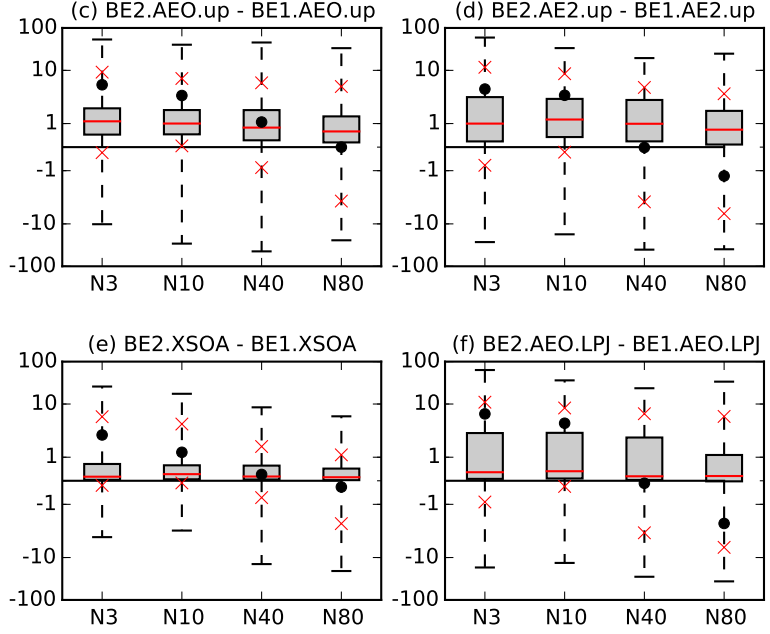

Figure 10. Global percent changes in N3, N10, N40, and N80 for biogenic emissions from 1000 to 2000 on a logarithmic scale for the simulations (a) BE2.AEO.meg-BE1.AEO.meg, (b) BE2.AE2.meg-BE1.AE2.meg, (c), BE2.AEO.up-BE1.AEO.up, (d) BE2.AE2.up-BE1.AE2.up, (e) BE2.XSOA-BE1.XSOA, and (f) BE2.AEO.LPJ-BE1.AEO.LPJ. The black dots indicate the global mean, the red line is the global median, the grey boxes are the interquartile range, the whiskers are the global maximum and minimum changes and the red Xs indicate the 5 th and 95 th percentiles (see Table 2).

tive forcing associated with increases in N80 in both the Southern Hemisphere and Northern Hemisphere mid-latitude westerlies with regional cloud-albedo AIEs in excess of
$-0.10 \mathrm{~W} \mathrm{~m}^{-2}$. The subtropical marine clouds in these regions are sensitive to changes in $\mathrm{CCN}$ number concentration, giving a strong cooling effect. This band of negative radiative forcing is caused by increased number concentrations of CCN-sized particles (N40 and N80) above the BL (Fig. 5). The increases in $\mathrm{CCN}$-sized particles aloft causes increases in CDNC in the vertical layers with the highest cloud fractions $(\sim 700 \mathrm{hPa})$ and thus a net cooling effect. There are also regions that experience a small positive cloud-albedo AIE due to changing BVOC emissions (e.g., southeastern North America, western Europe, and southeastern Australia) associated with regions of decreased N80.

Figure 11d shows the cloud-albedo AIE due to changing BVOC emissions between year 1000 and year 2000 with LPJ-GUESS BVOC emissions and anthropogenic emissions off (BE2.AEO.LPJ-BE1.AEO.LPJ), giving a global annual mean cloud-albedo AIE of $-0.008 \mathrm{~W} \mathrm{~m}^{-2}$. The global annual mean cloud-albedo AIE calculated using the LPJGUESS emissions is lower in magnitude than that calculated using the MEGAN emissions. This occurs because the LPJ-GUESS simulations exhibit smaller decreases in N80 over the oceanic regions when compared to the MEGAN simulations. There is also a stronger warming effect over regions such as central North America, southeastern South America, central Africa, and central Eurasia due to the decrease in N80. Figure 11e shows the combined aerosol radiative effect due to changing BVOC emissions between year 1000 and year 2000 with MEGAN BVOC emissions and anthropogenic emissions off (BE2.AEO.meg-BE1.AEO.meg) with a global mean warming of $+0.049 \mathrm{~W} \mathrm{~m}^{-2}$. The cooling effect from the cloud-albedo AIE (Fig. 11c) over oceanic regions tends to be canceled out due to the warming effect from the DRE (Fig. 11a), and the regional warming effect from the DRE dominates the total radiative effect. Figure $11 \mathrm{f}$ shows the combined aerosol radiative effect due to changing BVOC emissions between year 1000 and year 2000 with LPJ-GUESS BVOC emissions and anthropogenic emissions off (BE2.AEO.LPJ-BE1.AEO.LPJ) with a global mean 
(a) Aerosol Direct Effect MEGAN

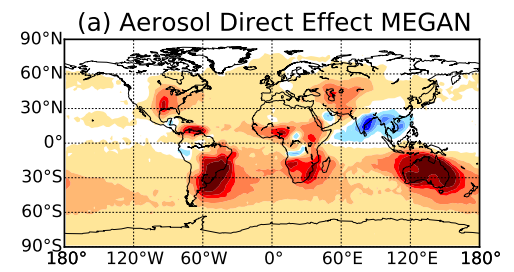

$90^{\circ} \mathrm{N}$ (c) Aerosol Indirect Effect MEGAN

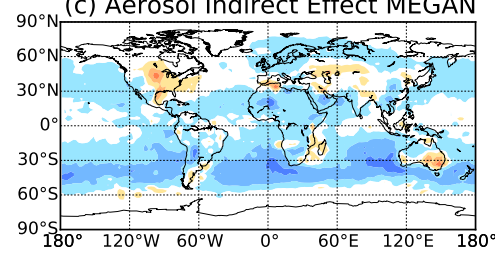

${ }_{90}(\mathrm{e})$ Combined Radiative Effect MEGAN

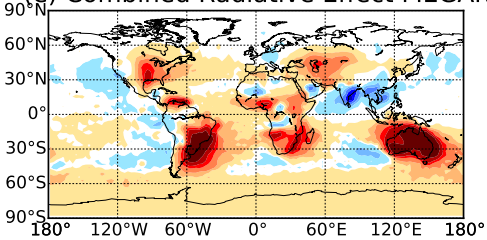

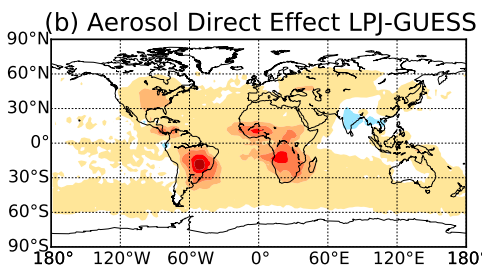

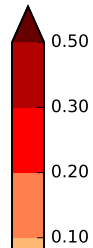

${ }_{90}$ (d) Aerosol Indirect Effect LPJ-GUESS

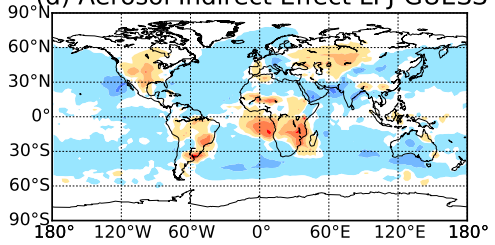

(f) Combined Radiative Effect LPJ-GUESS

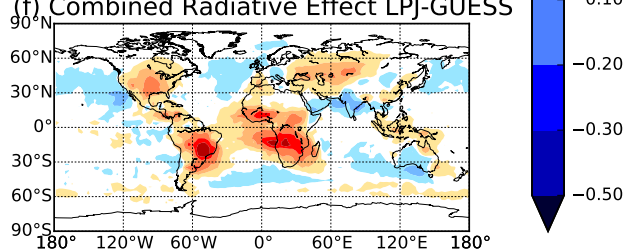

Figure 11. Annual mean change between year 1000 and year 2000 in (a) DRE with MEGAN BVOC emissions and anthropogenic emissions off (BE2.AEO.meg-BE1.AEO.meg), (b) DRE with LPJ-GUESS BVOC emissions and anthropogenic emissions off (BE2.AEO.LPJBE1.AEO.LPJ), (c) AIE with MEGAN BVOC emissions and anthropogenic emissions off, (d) AIE with LPJ-GUESS BVOC emissions and anthropogenic emissions off, (e) combined radiative effect with MEGAN BVOC emissions and anthropogenic emissions off, and (f) combined radiative effect with LPJ-GUESS BVOC emissions and anthropogenic emissions off. Global mean changes are $+0.065,+0.022$, $-0.020,-0.008,+0.049$, and $+0.015 \mathrm{~W} \mathrm{~m}^{-2}$, respectively (see Table 3 ).

warming of $+0.015 \mathrm{~W} \mathrm{~m}^{-2}$. Similar to Fig. 11e, the AIE cooling effect over oceanic regions is balanced by the warming effect in the same regions due to the increases in DRE. Therefore, the warming effect from the DRE dominates the total radiative effect. The additional significance of Fig. 11 is that it shows the forcing error resulting from holding biological emissions fixed when calculating anthropogenic radiative forcings from pre-industrial to the present day. Thus, the error in the anthropogenic forcing maybe on the order of $0.5 \mathrm{~W} \mathrm{~m}^{-2}$ over various regions if these changes in biogenic emissions are not included.

We also explored the aerosol radiative effect under the assumption of upper-bound SOA yields. With this upperbound yield changing MEGAN BVOC emissions from year 1000 to year 2000 with present-day anthropogenic emissions (2005) (BE2.AE2.up-BE1.AE2.up) resulted in a global mean DRE of $+0.163 \mathrm{~W} \mathrm{~m}^{-2}$ (a factor 3.2 greater than under standard SOA yields) and the global mean cloud-albedo AIE to $-0.056 \mathrm{~W} \mathrm{~m}^{-2}$ (factor 1.6 greater than standard SOA yield). The radiative effect due to changing BVOC emissions is therefore sensitive to assumptions about SOA yield.

\subsection{Discussion of model limitations}

There are certain limitations associated with our assumptions and model setup used in this study. Organic emissions do not participate in the nucleation process within GEOSChem-TOMAS; however, the inclusion of oxidized organic vapors may increase the sensitivity of particle number concentrations to changes in BVOC emissions, particularly in monoterpene-emitting regions known to produce extremely low volatile organic compounds (Riccobono et al., 2014; Scott et al., 2014). This inclusion of organic vapors in the nucleation process would also increase the pre-industrial (year 1000) baseline number concentrations (Scott et al., 2014). The SOA yields in GEOS-Chem-TOMAS are fixed; however, these yields may change with total organic mass, $\mathrm{NO}_{\mathrm{x}}$ concentrations, and changes in atmospheric oxidants. The change in SOA formation has no influence on the oxidation fields in GEOS-Chem-TOMAS and, therefore, there may be missing feedback mechanisms on key atmospheric oxidants as BVOCs are removed from the model system without changing model $\mathrm{OH}$ concentrations. This model also ignores $\mathrm{OH}$ recycling mechanisms that may accompany changes in isoprene oxidation, which may impact oxidation rates and SOA yields. SOA formation by $\mathrm{NO}_{3}$ is not included in this model - while this is likely minor for much of the globe, we may be underestimating SOA formed in areas influenced by monoterpenes and $\mathrm{NO}_{\mathrm{x}}$. Also, the inclusion of an additional $100 \mathrm{Tg} \mathrm{yr}^{-1}$ of anthropogenically enhanced SOA is relevant for present-day conditions; however, it is likely not representative of the pre-industrial atmosphere. This change in an- 
thropogenically enhanced SOA will cause additional uncertainties in our predictions, by changing the organic aerosol mass, which affect SOA growth rates and yields. The BVOC reconstructions also inherently have uncertainties associated with them. The response of plant emissions to environmental changes including $\mathrm{CO}_{2}$ and temperature is contentious, particularly with respect to monoterpene and sesquiterpene emission. Plant BVOC emissions respond differently to $\mathrm{CO}_{2}$ exposure in the short-term vs. $\mathrm{CO}_{2}$ exposure in the longterm (i.e., BVOC emissions of plants exposed to elevated $\mathrm{CO}_{2}$ for minutes or hours are different from BVOC emissions plants exposed to elevated $\mathrm{CO}_{2}$ from seed germination) (Heald et al., 2009). Perhaps more important for this study, the temperature dependence of BVOC emissions included in the emission models are typically based on short-term leaflevel exposure, and ignore the potential for plants to adapt to increasing temperature. Both MEGAN and LPJ-GUESS have been separately evaluated against observations (Arneth et al., 2007; Schurgers et al., 2009; Guenther et al., 2006) and compared to each other (Arneth et al., 2011; Guenther et al., 2012); however, without long-term measurements of BVOC fluxes there may be bias in the reconstructions towards the available short-term measurements used to develop the reconstructions. Experimental limitations in emission factors for the various plant functional types used to create the reconstruction also lead to uncertainties in the BVOC reconstructions. Finally, there is no way to directly test the emissions for the historic simulations. We expect the general spatial patterns to be robust, not necessarily the magnitudes.

\section{Conclusions}

In this study, we investigated the impact of millennial changes in biogenic volatile organic compound (BVOC) emissions on secondary organic aerosol (SOA) formation and global aerosol size distributions, and we calculated the associated aerosol radiative forcing. We used the global aerosol microphysics model GEOS-Chem-TOMAS to connect the historical changes in BVOC emissions to particle size distributions and the number concentration of cloud condensation nuclei (CCN).

This study built off recent work by Acosta Navarro et al. (2014), who determined how BVOC emissions have changed in the past millennium due to changes in land use, temperature, and carbon dioxide $\left(\mathrm{CO}_{2}\right)$ concentrations. They used two model reconstructions including three dominant classes of BVOC emissions (isoprene, monoterpenes, and sesquiterpenes) to simulate decadal-averaged monthly mean emissions over the time period 1000-2000. Their emissions reconstructions predicted that isoprene emissions decreased over the past millennium (due mainly to anthropogenic land-use changes), whereas monoterpene and sesquiterpene emissions increased (due predominantly to temperature increases). In our work, we included these mil- lennial emissions into the GEOS-Chem-TOMAS chemicaltransport model with online aerosol microphysics for SOA production only (no influence on the oxidant fields). We assumed that isoprene, monoterpenes, and sesquiterpenes form SOA in GEOS-Chem-TOMAS via fixed yields of 3,10, and $20 \%$, respectively.

When anthropogenic emissions (e.g., $\mathrm{SO}_{2}, \mathrm{NO}_{\mathrm{x}}$, primary aerosols) were turned off to represent pre-industrial conditions and emissions of isoprene, monoterpenes, and sesquiterpenes changed from year 1000 values ("preindustrial") to year 2000 values ("present day") using both BVOC reconstructions, N80 (the number of particles with diameter greater than $80 \mathrm{~nm}$, our proxy for $\mathrm{CCN}$ in this study) had decreases of greater than $25 \%$ in year 2000 relative to year 1000 that were predicted in regions with extensive land-use changes such as southern South America, southern Africa, southeastern North America, and southeastern Australia since year 1000. This significant change in N80 was predominantly driven by anthropogenic changes in high BVOC-emitting vegetation to lower-emitting crops/grazing land. Similar sensitivities in N80 exist when BVOC emissions were changed over the same time period but with anthropogenic emissions set to present-day values. Including recent work by Spracklen et al. (2011) and D'Andrea et al. (2013), the sensitivity to an additional $100 \mathrm{Tg} \mathrm{yr}^{-1}$ of anthropogenically enhanced SOA was tested, with BVOC emissions changed from year 1000 to year 2000 values, resulting in globally averaged decreases in N80 of $0.3 \%$. However, similar to the previous simulations, there are regional decreases exceeding $25 \%$. The sensitivity to SOA yields was also investigated by comparing simulations for year 1000 and 2000 BVOC emissions (with anthropogenic emissions both on and off) by increasing the yields from the base case of 3 , 10 , and $20 \%$ for isoprene, monoterpenes, and sesquiterpenes to 10,20 , and $40 \%$, respectively. This significant increase (at least a doubling) in SOA formation resulted in a nonlinear increase in the magnitude of the changes in particle number concentrations of all sizes (doubling yields did not double changes in particle number concentrations); however, it confirmed the same trend by globally decreasing N80. There are uncertainties in assuming fixed SOA yields however, as SOA yields are dependent on conditions such as aerosol loading and $\mathrm{NO}_{\mathrm{x}}$ concentrations, and therefore it might not be fixed with time.

The aerosol radiative effects associated with this millennial change in BVOC emissions were also investigated. Globally, with anthropogenic emissions off and changing BVOC emissions from year 1000 to 2000 , there is an annual mean $+0.065 \mathrm{~W} \mathrm{~m}^{-2}$ warming due to the aerosol direct effect (decrease in scattering of incoming solar radiation from decreased number concentrations of N80). However, there are regions such as southeastern South America, southern Africa, and Australia where the warming effect due to the DRE exceeds $+0.50 \mathrm{~W} \mathrm{~m}^{-2}$. The cloud-albedo (first) aerosol indirect effect was also calculated for the same sim- 
ulations indicating a global annual mean cloud-albedo AIE of $-0.020 \mathrm{~W} \mathrm{~m}^{-2}$, with most of the cooling effect occurring over oceanic regions (with high sensitivities and susceptibilities to changes in cloud properties) due to a small increase in N80 downwind of regions decreased BVOC emissions.

There are substantial uncertainties in emissions of BVOC and SOA yield. Additionally, the magnitude of the forcing of the biogenic changes differs depending on whether anthropogenic emissions are on or off. When we account for these uncertainties, the net global mean DRE due to millennial change in BVOC emissions is estimated to be between +0.022 and $+0.163 \mathrm{~W} \mathrm{~m}^{-2}$ and the net global mean cloud-albedo AIE is estimated to be between -0.008 and $-0.056 \mathrm{~W} \mathrm{~m}^{-2}$. Our calculated range in direct effect brackets the $+0.09 \mathrm{~W} \mathrm{~m}^{-2}$ global mean DRE recently estimated by Unger (2014), where biogenic emissions changed only due to year 1850 to 2000 anthropogenic land-use change. Overall, we find that millennial changes in BVOC emissions warm the climate, with the combined radiative effect (DRE plus cloud-albedo AIE) estimated to be between +0.015 and $+0.118 \mathrm{~W} \mathrm{~m}^{-2}$. We therefore find that anthropogenic land-use change, which dominates our calculated changes to BVOC emissions, warms climate through reducing the SOA burden. Reductions in BVOC emissions also impact other short-lived climate forcers (SLCF) including $\mathrm{O}_{3}$, $\mathrm{OH}$, and $\mathrm{CH}_{4}$ (Unger, 2014). However, the large uncertainty in the aerosol radiative effect precludes an accurate assessment of the net impact of land-use change on climate through SLCFs. An improved understanding of the atmospheric impacts of BVOCs is required before the net impact of land-use change on climate through SLCFs can be accurately determined. Research priorities include improved understandings of BVOC oxidation mechanisms, SOA yields including interactions with anthropogenic emissions, and the role of BVOC oxidation products in particle formation.

The changes in $\mathrm{CCN}$ due to millennial changes in BVOC emissions are predicted to be non-trivial in many regions; however, other uncertainties influencing $\mathrm{CCN}$ number concentrations must also be considered (Lee et al., 2013), such as nucleation mechanisms (Pierce and Adams, 2009c; Reddington et al., 2011; Spracklen et al., 2008; Wang and Penner, 2009), amount and volatility of SOA (Spracklen et al., 2011; Riipinen et al., 2011; D'Andrea et al., 2013), amount and size of primary emissions (Adams and Seinfeld, 2003; Pierce and Adams, 2006, 2007, 2009c; Reddington et al., 2011; Spracklen et al., 2011), and wet deposition (Croft et al., 2012).

While present-day emissions of anthropogenic aerosols are a significant contributor to climate change, this study has shown the importance of anthropogenically driven changes in BVOC emissions over the past millennium on SOA formation, $\mathrm{CCN}$ number concentrations, and radiative forcing. The large decrease in $\mathrm{CCN}$ due to land-use changes over the past millennium appears to be a largely overlooked and important anthropogenic aerosol effect on regional climates. Fi- nally, these results show that present-day BVOC emissions should not be used in pre-industrial aerosol simulations as they may cause errors in the reference state of the atmosphere when calculating the radiative forcing due to anthropogenic activities.

Acknowledgements. We thank the Atlantic Computational Excellence Network (ACENet) for the computational resources used in this study. The authors acknowledge Natural Sciences and Engineering Research Council (NSERC) of Canada for funding through the Network on Climate and Aerosols (NETCARE) network. Financial support from the European Research Council (ERC-StG-ATMOGAIN grant no. 278277) and Vetenskapsrådet (grant no. 2011-5120) and Natural Environment Research Council (grant no. NE/K015966/1) is gratefully acknowledged.

Edited by: R. Krejci

\section{References}

Acosta Navarro, J. C., Smolander, S., Struthers, H., Zorita, E., Ekman, A. M. L., Kaplan, J. O., Guenther, A., Arneth, A. and Riipinen, I.: Global emissions of terpenoid VOCs from terrestrial vegetation in the last millennium, J. Geophys. Res.-Atmos., 119, 6867-6885, doi:10.1002/2013JD021238, 2014

Adams, P. J. and Seinfeld, J. H.: Disproportionate impact of particulate emissions on global cloud condensation nuclei concentrations, Geophys. Res. Lett., 30, 1210-1239, doi:10.1029/2002GL016303, 2003.

Arneth, A., Niinemets, Ü., Pressley, S., Bäck, J., Hari, P., Karl, T., Noe, S., Prentice, I. C., Serça, D., Hickler, T., Wolf, A., and Smith, B.: Process-based estimates of terrestrial ecosystem isoprene emissions: incorporating the effects of a direct $\mathrm{CO}_{2}$-isoprene interaction, Atmos. Chem. Phys., 7, 31-53, doi:10.5194/acp-7-31-2007, 2007.

Arneth, A., Schurgers, G., Lathiere, J., Duhl, T., Beerling, D. J., Hewitt, C. N., Martin, M., and Guenther, A.: Global terrestrial isoprene emission models: sensitivity to variability in climate and vegetation, Atmos. Chem. Phys., 11, 8037-8052, doi:10.5194/acp-11-8037-2011, 2011.

Bellouin, N., Rae, J., Jones, A., Johnson, C., Haywood, J., and Boucher, O.: Aerosol forcing in the Climate Model Intercomparison Project (CMIP5) simulations by HadGEM2-ES and the role of ammonium nitrate, J. Geophys. Res.-Atmos., 116, D20206, doi:10.1029/2011JD016074, 2011.

Bellouin, N., Mann, G. W., Woodhouse, M. T., Johnson, C., Carslaw, K. S., and Dalvi, M.: Impact of the modal aerosol scheme GLOMAP-mode on aerosol forcing in the Hadley Centre Global Environmental Model, Atmos. Chem. Phys., 13, 30273044, doi:10.5194/acp-13-3027-2013, 2013.

Benkovitz, C. M., Scholtz, M. T., Pacyna, J., Tarrason, L., Dignon, J., Voldner, E. C., Spiro, P. A., Logan, J. A., and Graedel, T. E.: Global gridded inventories of anthropogenic emissions of sulfur and nitrogen, J. Geophys. Res., 101, 239-29 254, 1996.

Boucher, O., Randall, D., Artaxo, P., Bretherton, C., Feingold, G., Forster, P., Kerminen, V.-M., Kondo, Y., Liao, H., Lohmann, U., Rasch, P., Satheesh, S., Sherwood, S., Stevens, B., and Zhang, 
X.: Clouds and Aerosols, in: Climate Change 2013: The Physical Science Basis. Contribution of Working Group I to the Fifth Assessment Report of the Intergovernmental Panel on Climate Change, edited by: Stocker, T., Qin, D., Plattner, G.-K., Tignor, M., Allen, S., Boschung, J., Nauels, A., Xia, Y., Bex, V., and Midgley, P., chap. 7, 571-657, Cambridge University Press, Cambridge, UK and New York, NY, USA, 2013.

Carlton, A. G., Wiedinmyer, C., and Kroll, J. H.: A review of Secondary Organic Aerosol (SOA) formation from isoprene, Atmos. Chem. Phys., 9, 4987-5005, doi:10.5194/acp-9-4987-2009, 2009.

Carlton, A. G., Bhave, P. V., Napelenok, S. L., Edney, E. O., Sarwar, G., Pinder, R. W., Pouliot, G. A. and Houyoux, M.: Model Representation of Secondary Organic Aerosol in CMAQv4.7, Environ. Sci. Technol., 44, 8553-8560, doi:10.1021/es100636q, 2010.

Carslaw, K. S., Boucher, O., Spracklen, D. V., Mann, G. W., Rae, J. G. L., Woodward, S., and Kulmala, M.: A review of natural aerosol interactions and feedbacks within the Earth system, Atmos. Chem. Phys., 10, 1701-1737, doi:10.5194/acp-10-17012010, 2010.

Carslaw, K. S., Lee, L. A., Reddington, C. L., Pringle, K. J., Rap, A., Forster, P. M., Mann, G. W., Spracklen, D. V, Woodhouse, M. T., Regayre, L. A., and Pierce, J. R.: Large contribution of natural aerosols to uncertainty in indirect forcing., Nature, 503, 67-71, doi:10.1038/nature12674, 2013.

Chung, S. H. and Seinfeld, J. H.: Global distribution and climate forcing of carbonaceous aerosols, J. Geophys. Res., 107, 4407, doi:10.1029/2001JD001397, 2002.

Chameides, W. L., Lindsay, R. W., Richardson, J., and Kiang, C. S: The Role of Biogenic Hydrocarbons in Urban Photochemical Smog: Atlanta as a Case Study, Science, 241, 1473-1475, 1998.

Charlson, R. J., Schwartz, S. E., Hales, J. M., Cess, R. D., Coakley Jr., J. A., Hansen, J. E., and Hofmann, D. J.: Climate forcing by anthropogenic aerosols, Science, 255, 423-430, 1992.

Clement, A. C., Burgman, R., and Norris, J. R.: Observational and Model Evidence for Positive Low-Level Cloud Feedback, Science, 325, 460-464, 2009.

Croft, B., Pierce, J. R., Martin, R. V., Hoose, C., and Lohmann, U.: Uncertainty associated with convective wet removal of entrained aerosols in a global climate model, Atmos. Chem. Phys., 12, 10725-10748, doi:10.5194/acp-12-10725-2012, 2012.

D’Andrea, S. D., Häkkinen, S. A. K., Westervelt, D. M., Kuang, C., Levin, E. J. T., Kanawade, V. P., Leaitch, W. R., Spracklen, D. V., Riipinen, I., and Pierce, J. R.: Understanding global secondary organic aerosol amount and size-resolved condensational behavior, Atmos. Chem. Phys., 13, 11519-11534, doi:10.5194/acp-1311519-2013, 2013.

De Gouw, J. A., Middlebrook, A. M., Warneke, C., Goldan, P. D., Kuster, W. C., Roberts, J. M., Fehsenfeld, F. C., Worsnop, D. R., Canagaratna, M. R., Pszenny, A. A. P., Keene, W. C., Marchewka, M., Bertman, S. B. and Bates, T. S.: Budget of organic carbon in a polluted atmosphere: Results from the New England Air Quality Study in 2002, J. Geophys. Res., 110, D16305, doi:10.1029/2004JD005623, 2005.

Donahue, N. M., Trump, E. R., Pierce, J. R., and Riipinen, I.: Theoretical constraints on pure vapor-pressure driven condensation of organics to ultrafine particles, Geophys. Res. Lett., 38, L16801, doi:10.1029/2011GL048115, 2011.
Dusek, U., Frank, G. P., Hildebrandt, L., Curtius, J., Schneider, J., Walter, S., Chand, D., Drewnick, F., Hings, S., Jung, D., Borrmann, S., and Andreae, M. O.: Size Matters More Than Chemistry for Cloud-Nucleating Ability of Aerosol Particles, Science, 312, 1375-1378, 2006.

Edwards, J. M. and Slingo, A.: Studies with a flexible new radiation code. I: Choosing a configuration for a large-scale model, Q. J. Roy. Meteor. Soc., 122, 689-719, 1996.

Ehn, M., Thornton, J. A., Kleist, E., Sipilä, M., Junninen, H., Pullinen, I., Springer, M., Rubach, F., Tillmann, R., Lee, B., LopezHilfiker, F., Andres, S., Acir, I.-H., Rissanen, M., Jokinen, T., Schobesberger, S., Kangasluoma, J., Kontkanen, J., Nieminen, T., Kurtén, T., Nielsen, L. B., Jørgensen, S., Kjaergaard, H. G., Canagaratna, M., Maso, M. D., Berndt, T., Petäjä, T., Wahner, A., Kerminen, V.-M., Kulmala, M., Worsnop, D. R., Wildt, J., and Mentel, T. F.: A large source of low-volatility secondary organic aerosol., Nature, 506, 476-479, doi:10.1038/nature13032, 2014.

Forster, P., Ramaswamy, V., Artaxo, P., Berntsen, T., Betts, R., Fahey, D. W., Haywood, J., Lean, J., Lowe, D. C., Myhre, G., Nganga, J., Prinn, R., Raga, G., Schulz, M., and Dorland, R. $\mathrm{V}$ : Changes in atmospheric constituents and in radiative forcing, in: Climate change 2007: the physical science basis. contribution of working group I to the fourth assessment report of the intergovernmental panel on climate change, edited by: Solomon, S., Qin, D., Manning, M., Chen, Z., Marquis, M., Averyt, K. B., Tignor, M., and Miller, H. L., 129-234, Cambridge University Press, Cambridge, UK and New York, NY, USA, 2007.

Griffin, R. J., Cocker, D. R., Flagan, R. C. and Seinfeld, J. H.: Organic aerosol formation from the oxidation of biogenic hydrocarbons, J. Geophys. Res., 104, 3555-3567, doi:10.1029/1998JD100049, 1999.

Guenther, A., Karl, T., Harley, P., Wiedinmyer, C., Palmer, P. I., and Geron, C.: Estimates of global terrestrial isoprene emissions using MEGAN (Model of Emissions of Gases and Aerosols from Nature), Atmos. Chem. Phys., 6, 3181-3210, doi:10.5194/acp-63181-2006, 2006.

Guenther, A. B., Jiang, X., Heald, C. L., Sakulyanontvittaya, T., Duhl, T., Emmons, L. K., and Wang, X.: The Model of Emissions of Gases and Aerosols from Nature version 2.1 (MEGAN2.1): an extended and updated framework for modeling biogenic emissions, Geosci. Model Dev., 5, 1471-1492, doi:10.5194/gmd-51471-2012, 2012.

Hallquist, M., Wenger, J. C., Baltensperger, U., Rudich, Y., Simpson, D., Claeys, M., Dommen, J., Donahue, N. M., George, C., Goldstein, A. H., Hamilton, J. F., Herrmann, H., Hoffmann, T., Iinuma, Y., Jang, M., Jenkin, M. E., Jimenez, J. L., Kiendler-Scharr, A., Maenhaut, W., McFiggans, G., Mentel, Th. F., Monod, A., Prévôt, A. S. H., Seinfeld, J. H., Surratt, J. D., Szmigielski, R., and Wildt, J.: The formation, properties and impact of secondary organic aerosol: current and emerging issues, Atmos. Chem. Phys., 9, 5155-5236, doi:10.5194/acp-9-51552009, 2009.

Heald, C. L., Henze, D. K., Horowitz, L. W., Feddema, J., Lamarque, J.-F., Guenther, A., Hess, P. G., Vitt, F., Seinfeld, J. H., Goldstein, A. H., and Fung, I.: Predicted change in global secondary organic aerosol concentrations in response to future climate, emissions, and land use change, J. Geophys. Res.-Atmos., 113, D05211, doi:10.1029/2007JD009092, 2008. 
Heald, C. L., Wilkinson, M. J., Monson, R. K., Alo, C. A., Wang, G., and Guenther, A.: Response of isoprene emission to ambient $\mathrm{CO} 2$ changes and implications for global budgets, Glob. Change Biol., 15, 1127-1140, doi:10.1111/j.1365-2486.2008.01802.x, 2009.

Hoffmann, T., Odum, J. R., Bowman, F., Collins, D., Klockow, D., Flagan, R. C. and Seinfeld, J. H.: Formation of Organic Aerosols from the Oxidation of Biogenic Hydrocarbons, J. Atmos. Chem., 26, 189-222, doi:10.1023/A:1005734301837, 1997.

Jimenez, J. L., Canagaratna, M. R., Donahue, N. M., Prevot, A. S. H., Zhang, Q., Kroll, J. H., DeCarlo, P. F., Allan, J. D., Coe, H., Ng, N. L., Aiken, A. C., Docherty, K. S., Ulbrich, I. M., Grieshop, A. P., Robinson, A. L., Duplissy, J., Smith, J. D., Wilson, K. R., Lanz, V. A., Hueglin, C., Sun, Y. L., Tian, J., Laaksonen, A., Raatikainen, T., Rautiainen, J., Vaattovaara, P., Ehn, M., Kulmala, M., Tomlinson, J. M., Collins, D. R., Cubison, M. J., Dunlea, E. J., Huffman, J. A., Onasch, T. B., Alfarra, M. R., Williams, P. I., Bower, K., Kondo, Y., Schneider, J., Drewnick, F., Borrmann, S., Weimer, S., Demerjian, K., Salcedo, D., Cottrell, L., Griffin, R., Takami, A., Miyoshi, T., Hatakeyama, S., Shimono, A., Sun, J. Y., Zhang, Y. M., Dzepina, K., Kimmel, J. R., Sueper, D., Jayne, J. T., Herndon, S. C., Trimborn, A. M., Williams, L. R., Wood, E. C., Middlebrook, A. M., Kolb, C. E., Baltensperger, U., and Worsnop, D. R.: Evolution of organic aerosols in the atmosphere., Science, 326, 1525-1529, doi:10.1126/science.1180353, 2009.

Jung, J., Fountoukis, C., Adams, P. J., and Pandis, S. N.: Simulation of in situ ultrafine particle formation in the eastern United States using PMCAMx-UF, J. Geophys. Res., 115, D03203, doi:10.1029/2009JD012313, 2010.

Kaplan, J. O., Krumhardt, K. M., Ellis, E. C., Ruddiman, W. F., Lemmen, C., and Goldewijk, K. K.: Holocene carbon emissions as a result of anthropogenic land cover change, The Holocene, 21, 775-791, 2011.

Kanakidou, M., Seinfeld, J. H., Pandis, S. N., Barnes, I., Dentener, F. J., Facchini, M. C., Van Dingenen, R., Ervens, B., Nenes, A., Nielsen, C. J., Swietlicki, E., Putaud, J. P., Balkanski, Y., Fuzzi, S., Horth, J., Moortgat, G. K., Winterhalter, R., Myhre, C. E. L., Tsigaridis, K., Vignati, E., Stephanou, E. G., and Wilson, J.: Organic aerosol and global climate modelling: a review, Atmos. Chem. Phys., 5, 1053-1123, doi:10.5194/acp-5-1053-2005, 2005.

Kerminen, V.-M. and Kulmala, M.: Analytical formulae connecting the "real" and the "apparent" nucleation rate and the nuclei number concentration for atmospheric nucleation events, J. Aerosol Sci., 33, 609-622, 2002.

Kerminen, V.-M., Paramonov, M., Anttila, T., Riipinen, I., Fountoukis, C., Korhonen, H., Asmi, E., Laakso, L., Lihavainen, H., Swietlicki, E., Svenningsson, B., Asmi, A., Pandis, S. N., Kulmala, M., and Petäjä, T.: Cloud condensation nuclei production associated with atmospheric nucleation: a synthesis based on existing literature and new results, Atmos. Chem. Phys., 12, 1203712059, doi:10.5194/acp-12-12037-2012, 2012.

Kroll, J. H. and Seinfeld, J. H.: Chemistry of secondary organic aerosol: Formation and evolution of low-volatility organics in the atmosphere, Atmos. Environ., 42, 3593-3624, 2008.

Kroll, J. H., Ng, N. L., Murphy, S. M., Flagan, R. C., and Seinfeld, J. H.: Secondary organic aerosol formation from isoprene pho- tooxidation under high-NO $\mathrm{NO}_{x}$ conditions, Geophys. Res. Lett., 40, 1869-1877, 2006.

Kuang, C., McMurry, P. H., and McCormick, A. V: Determination of cloud condensation nuclei production from measured new particle formation events, Geophys. Res. Lett., 36, L09822, doi:10.1029/2009GL037584, 2009.

Kulmala, M., Vehkamäki, H., Petäjä, T., Dal Maso, M., Lauri, A., Kerminen, V.-M., Birmili, W., and McMurry, P. H.: Formation and growth of ultrafine atmospheric particles: A review of observations, J. Aerosol Sci., 35, 143-176, 2004.

Lamsal, L. N., Martin, R. V., Van Donkelaar, A., Steinbacher, M., Celarier, E. A., Bucsela, E., Dunlea, E. J., and Pinto, J. P.: Ground-level nitrogen dioxide concentrations inferred from the satellite-borne Ozone Monitoring Instrument, J. Geophys. Res.Atmos., 113, D16308, doi:10.1029/2007JD009235, 2008.

Lee, L. A., Pringle, K. J., Reddington, C. L., Mann, G. W., Stier, P., Spracklen, D. V., Pierce, J. R., and Carslaw, K. S.: The magnitude and causes of uncertainty in global model simulations of cloud condensation nuclei, Atmos. Chem. Phys., 13, 8879-8914, doi:10.5194/acp-13-8879-2013, 2013.

Lee, Y. H. and Adams, P. J.: A Fast and Efficient Version of the TwO-Moment Aerosol Sectional (TOMAS) Global Aerosol Microphysics Model, Aerosol Sci. Tech., 46, 678-689, doi:10.1080/02786826.2011.643259, 2011.

Liao, L., Kerminen, V.-M., Boy, M., Kulmala, M., and Dal Maso, M.: Temperature influence on the natural aerosol budget over boreal forests, Atmos. Chem. Phys., 14, 8295-8308, doi:10.5194/acp-14-8295-2014, 2014.

Lim, Y. B., Tan, Y., Perri, M. J., Seitzinger, S. P., and Turpin, B. J.: Aqueous chemistry and its role in secondary organic aerosol (SOA) formation, Atmos. Chem. Phys., 10, 1052110539, doi:10.5194/acp-10-10521-2010, 2010.

Makkonen, R., Asmi, A., Kerminen, V.-M., Boy, M., Arneth, A., Guenther, A., and Kulmala, M.: BVOC-aerosol-climate interactions in the global aerosol-climate model ECHAM5.5-HAM2, Atmos. Chem. Phys., 12, 10077-10096, doi:10.5194/acp-1210077-2012, 2012.

McFiggans, G., Artaxo, P., Baltensperger, U., Coe, H., Facchini, M. C., Feingold, G., Fuzzi, S., Gysel, M., Laaksonen, A., Lohmann, U., Mentel, T. F., Murphy, D. M., O’Dowd, C. D., Snider, J. R., and Weingartner, E.: The effect of physical and chemical aerosol properties on warm cloud droplet activation, Atmos. Chem. Phys., 6, 2593-2649, doi:10.5194/acp-6-2593-2006, 2006.

Napari, I., Noppel, M., Vehkamäki, H., and Kulmala, M.: Parametrization of ternary nucleation rates for $\mathrm{H}_{2} \mathrm{SO}_{4}$ $\mathrm{NH}_{3}-\mathrm{H}_{2} \mathrm{O}$ vapors, J. Geophys. Res.-Atmos., 107, 4381, doi:10.1029/2002JD002132, 2002.

Nenes, A. and Seinfeld, J. H.: Parameterization of cloud droplet formation in global climate models, J. Geophys. Res.-Atmos, 108, 4415, doi:10.1029/2002JD002911, 2003.

Nenes, A., Pandis, S. N., and Pilinis, C.: ISORROPIA: A New Thermodynamic Equilibrium Model for Multiphase Multicomponent Inorganic Aerosols, Aquat. Geochem., 4, 123-152, doi:10.1023/A:1009604003981, 1998.

Paasonen, P., Asmi, A., Petaja, T., Kajos, M. K., Aijala, M., Junninen, H., Holst, T., Abbatt, J. P. D., Arneth, A., Birmili, W., van der Gon, H. D., Hamed, A., Hoffer, A., Laakso, L., Laaksonen, A., Leaitch, W. R., Plass-Dulmer, C., Pryor, S. C., Raisanen, P., Swietlicki, E., Wiedensohler, A., Worsnop, D. R., Kerminen, 
V.-M., and Kulmala, M.: Warming-induced increase in aerosol number concentration likely to moderate climate change, Nat. Geosci, 6, 438-442, 2013.

Pacifico, F., Folberth, G. A., Jones, C. D., Harrison, S. P., and Collins, W. J.: Sensitivity of biogenic isoprene emissions to past, present, and future environmental conditions and implications for atmospheric chemistry, J. Geophys. Res., 117, D22302, doi:10.1029/2012JD018276, 2012.

Peñuelas, J. and Staudt, M.: BVOCs and global change, Trends in Plant Science, 15, 133-144, doi:10.1016/j.tplants.2009.12.005, 2010.

Petters, M. D. and Kreidenweis, S. M.: A single parameter representation of hygroscopic growth and cloud condensation nucleus activity - Part 3: Including surfactant partitioning, Atmos. Chem. Phys., 13, 1081-1091, doi:10.5194/acp-13-1081-2013, 2013.

Pierce, J. R. and Adams, P. J.: Global evaluation of CCN formation by direct emission of sea salt and growth of ultrafine sea salt, J. Geophys. Res.-Atmos., 111, D06203, doi:10.1029/2005JD006186, 2006.

Pierce, J. R. and Adams, P. J.: Efficiency of cloud condensation nuclei formation from ultrafine particles, Atmos. Chem. Phys., 7, 1367-1379, doi:10.5194/acp-7-1367-2007, 2007.

Pierce, J. R. and Adams, P. J.: Uncertainty in global CCN concentrations from uncertain aerosol nucleation and primary emission rates, Atmos. Chem. Phys., 9, 1339-1356, doi:10.5194/acp-91339-2009, 2009.

Pierce, J. R., Riipinen, I., Kulmala, M., Ehn, M., Petäjä, T., Junninen, H., Worsnop, D. R., and Donahue, N. M.: Quantification of the volatility of secondary organic compounds in ultrafine particles during nucleation events, Atmos. Chem. Phys., 11, 90199036, doi:10.5194/acp-11-9019-2011, 2011.

Pierce, J. R., Evans, M. J., Scott, C. E., D’Andrea, S. D., Farmer, D. K., Swietlicki, E., and Spracklen, D. V.: Weak global sensitivity of cloud condensation nuclei and the aerosol indirect effect to Criegee $+\mathrm{SO}_{2}$ chemistry, Atmos. Chem. Phys., 13, 3163-3176, doi:10.5194/acp-13-3163-2013, 2013.

Putaud, J.-P., Van Dingenen, R., Dell'Acqua, A., Raes, F., Matta, E., Decesari, S., Facchini, M. C., and Fuzzi, S.: Size-segregated aerosol mass closure and chemical composition in Monte Cimone (I) during MINATROC, Atmos. Chem. Phys., 4, 889-902, doi:10.5194/acp-4-889-2004, 2004.

Pye, H. O. T., Chan, A. W. H., Barkley, M. P., and Seinfeld, J. H.: Global modeling of organic aerosol: the importance of reactive nitrogen $\left(\mathrm{NO}_{\mathrm{x}}\right.$ and $\left.\mathrm{NO}_{3}\right)$, Atmos. Chem. Phys., 10, 1126111276, doi:10.5194/acp-10-11261-2010, 2010.

Rap, A., Scott, C. E., Spracklen, D. V., Bellouin, N., Forster, P. M., Carslaw, K. S., Schmidt, A., and Mann, G.: Natural aerosol direct and indirect radiative effects., Geophys. Res. Lett., 40, $3297-$ 3301, 2013.

Reddington, C. L., Carslaw, K. S., Spracklen, D. V., Frontoso, M. G., Collins, L., Merikanto, J., Minikin, A., Hamburger, T., Coe, H., Kulmala, M., Aalto, P., Flentje, H., Plass-Dülmer, C., Birmili, W., Wiedensohler, A., Wehner, B., Tuch, T., Sonntag, A., O’Dowd, C. D., Jennings, S. G., Dupuy, R., Baltensperger, U., Weingartner, E., Hansson, H.-C., Tunved, P., Laj, P., Sellegri, K., Boulon, J., Putaud, J.-P., Gruening, C., Swietlicki, E., Roldin, P., Henzing, J. S., Moerman, M., Mihalopoulos, N., Kouvarakis, G., Z dímal, V., Zíková, N., Marinoni, A., Bonasoni, P., and Duchi, R.: Primary versus secondary contributions to particle number concentrations in the European boundary layer, Atmos. Chem. Phys., 11, 12007-12036, doi:10.5194/acp-11-12007-2011, 2011. Riccobono, F., Schobesberger, S., Scott, C. E., Dommen, J., Ortega, I. K., Rondo, L., Almeida, J., Amorim, A., Bianchi, F., Breitenlechner, M., David, A., Downard, A., Dunne, E. M., Duplissy, J., Ehrhart, S., Flagan, R. C., Franchin, A., Hansel, A., Junninen, H., Kajos, M., Keskinen, H., Kupc, A., Kürten, A., Kvashin, A. N., Laaksonen, A., Lehtipalo, K., Makhmutov, V., Mathot, S., Nieminen, T., Onnela, A., Petäjä, T., Praplan, A. P., Santos, F. D., Schallhart, S., Seinfeld, J. H., Sipilä, M., Spracklen, D. V, Stozhkov, Y., Stratmann, F., Tomé, A., Tsagkogeorgas, G., Vaattovaara, P., Viisanen, Y., Vrtala, A., Wagner, P. E., Weingartner, E., Wex, H., Wimmer, D., Carslaw, K. S., Curtius, J., Donahue, N. M., Kirkby, J., Kulmala, M., Worsnop, D. R., and Baltensperger, U.: Oxidation products of biogenic emissions contribute to nucleation of atmospheric particles., Science, 344, 717-721, doi:10.1126/science.1243527, 2014.

Riipinen, I., Pierce, J. R., Yli-Juuti, T., Nieminen, T., Häkkinen, S., Ehn, M., Junninen, H., Lehtipalo, K., Petäjä, T., Slowik, J., Chang, R., Shantz, N. C., Abbatt, J., Leaitch, W. R., Kerminen, V.-M., Worsnop, D. R., Pandis, S. N., Donahue, N. M., and Kulmala, M.: Organic condensation: a vital link connecting aerosol formation to cloud condensation nuclei (CCN) concentrations, Atmos. Chem. Phys., 11, 3865-3878, doi:10.5194/acp-11-38652011, 2011.

Riipinen, I., Yli-Juuti, T., Pierce, J. R., Petäjä, T., Worsnop, D. R., Kulmala, M., and Donahue, N. M.: The contribution of organics to atmospheric nanoparticle growth, Nature Geosci., 5, 453-458, doi:10.1038/ngeo1499, 2012.

Rosenfeld, D., Lohmann, U., Raga, G. B., O’Dowd, C. D., Kulmala, M., Fuzzi, S., Reissell, A., and Andreae, M. O.: Flood or Drought: How Do Aerosols Affect Precipitation?, Science, 312, 1309-1313, 2008.

Rossow, W. B. and Schiffer, R. A.: Advances in understanding clouds from ISCCP, B. Am. Meteorol. Soc., 80, 2261-2288, 1999.

Schurgers, G., Hickler, T., Miller, P. A., and Arneth, A.: European emissions of isoprene and monoterpenes from the Last Glacial Maximum to present, Biogeosciences, 6, 2779-2797, doi:10.5194/bg-6-2779-2009, 2009.

Scott, C. E., Rap, A., Spracklen, D. V., Forster, P. M., Carslaw, K. S., Mann, G. W., Pringle, K. J., Kivekäs, N., Kulmala, M., Lihavainen, H., and Tunved, P.: The direct and indirect radiative effects of biogenic secondary organic aerosol, Atmos. Chem. Phys., 14, 447-470, doi:10.5194/acp-14-447-2014, 2014.

Sipilä, M., Berndt, T., Petäjä, T., Brus, D., Vanhanen, J., Stratmann, F., Patokoski, J., Mauldin III, R. L., Hyvärinen, A.-P., Lihavainen, H., and Kulmala, M.: Role of Sulfuric Acid in Atmospheric Nucleation, Science, 327, 1243-1246, 2010.

Sitch, S., Smith, B., Prentice, I. C., Arneth, A., Bondeau, A., Cramer, W., Kaplan, J. O., Levis, S., Lucht, W., Sykes, M. T., Thonicke, K., and Venevsky, S.: Evaluation of ecosystem dynamics, plant geography and terrestrial carbon cycling in the LPJ dynamic global vegetation model, Glob. Change Biol., 9, 161-185, 2003.

Smith, B., Prentice, I. C., and Sykes, M. T.: Representation of vegetation dynamics in the modelling of terrestrial ecosystems: comparing two contrasting approaches within European climate space, Global Ecol. Biogeogr., 10, 621-637, 2001. 
Spracklen, D. V, Carslaw, K. S., Kulmala, M., Kerminen, V. M., Sihto, S. L., Riipinen, I., Merikanto, J., Mann, G. W., Chipperfield, M. P., Wiedensohler, A., Birmili, W., and Lihavainen, H.: Contribution of particle formation to global cloud condensation nuclei concentrations, Geophys. Res. Lett., 35, D06808, doi:10.1029/2007GL033038, 2008.

Spracklen, D. V., Carslaw, K. S., Pöschl, U., Rap, A., and Forster, P. M.: Global cloud condensation nuclei influenced by carbonaceous combustion aerosol, Atmos. Chem. Phys., 11, 9067-9087, doi:10.5194/acp-11-9067-2011, 2011.

Stanier, C. O., Khlystov, A. Y. and Pandis, S. N.: Nucleation Events During the Pittsburgh Air Quality Study: Description and Relation to Key Meteorological, Gas Phase, and Aerosol Parameters, Aerosol Sci. Technol., 38, 253-264, 2004.

Tanaka, K., Kim, H.-J., Saito, K., Takahashi, H. G., Watanabe, M., Yokohata, T., Kimoto, M., Takata, K., and Yasunari, T.: How have both cultivation and warming influenced annual global isoprene and monoterpene emissions since the preindustrial era?, Atmos. Chem. Phys., 12, 9703-9718, doi:10.5194/acp-12-97032012, 2012.

Unger, N.: Isoprene emission variability through the twentieth century, J. Geophys. Res.-Atmos., 118, 13606-13613, doi:10.1002/2013JD020978, 2013.

Unger, N.: Human land-use-driven reduction of forest volatiles cools global climate, Nature Clim. Change, 4, 907-910, doi:10.1038/nclimate2347, 2014.

van Donkelaar, A., Martin, R. V., Leaitch, W. R., Macdonald, A. M., Walker, T. W., Streets, D. G., Zhang, Q., Dunlea, E. J., Jimenez, J. L., Dibb, J. E., Huey, L. G., Weber, R., and Andreae, M. O.: Analysis of aircraft and satellite measurements from the Intercontinental Chemical Transport Experiment (INTEX-B) to quantify long-range transport of East Asian sulfur to Canada, Atmos. Chem. Phys., 8, 2999-3014, doi:10.5194/acp-8-2999-2008, 2008.
Vehkamäki, H. and Riipinen, I.: Thermodynamics and kinetics of atmospheric aerosol particle formation and growth, Chem. Soc. Rev., 41, 5160-5173, doi:10.1039/c2cs00002d, 2012.

Wainwright, C. D., Pierce, J. R., Liggio, J., Strawbridge, K. B., Macdonald, A. M., and Leaitch, R. W.: The effect of model spatial resolution on Secondary Organic Aerosol predictions: a case study at Whistler, BC, Canada, Atmos. Chem. Phys., 12, 1091110923, doi:10.5194/acp-12-10911-2012, 2012.

Wang, M. and Penner, J. E.: Aerosol indirect forcing in a global model with particle nucleation, Atmos. Chem. Phys., 9, 239-260, doi:10.5194/acp-9-239-2009, 2009.

Ward, D. S., Mahowald, N. M., and Kloster, S.: Potential climate forcing of land use and land cover change, Atmos. Chem. Phys., 14, 12701-12724, doi:10.5194/acp-14-12701-2014, 2014.

Westervelt, D. M., Pierce, J. R., Riipinen, I., Trivitayanurak, W., Hamed, A., Kulmala, M., Laaksonen, A., Decesari, S., and Adams, P. J.: Formation and growth of nucleated particles into cloud condensation nuclei: model-measurement comparison, Atmos. Chem. Phys., 13, 7645-7663, doi:10.5194/acp-13-76452013, 2013.

Wu, S., Mickley, L. J., Kaplan, J. O., and Jacob, D. J.: Impacts of changes in land use and land cover on atmospheric chemistry and air quality over the 21 st century, Atmos. Chem. Phys., 12, 15971609, doi:10.5194/acp-12-1597-2012, 2012.

Xu, L., Kollman, M. S., Song, C., Shilling, J. E., and Ng, N. L.: Effects of $\mathrm{NO}_{x}$ on the volatility of secondary organic aerosol from isoprene photooxidation. Environ. Sci. Technol., 48, 22532262, doi:10.1021/es404842g, 2014. 